Portland State University

PDXScholar

1988

\title{
A Study of Principals' Leadership Behavior in One Suburban School District
}

Darleen Huber-Dilbeck

Portland State University

Follow this and additional works at: https://pdxscholar.library.pdx.edu/open_access_etds

Part of the Educational Assessment, Evaluation, and Research Commons, and the Educational Leadership Commons

Let us know how access to this document benefits you.

\section{Recommended Citation}

Huber-Dilbeck, Darleen, "A Study of Principals' Leadership Behavior in One Suburban School District" (1988). Dissertations and Theses. Paper 1311.

https://doi.org/10.15760/etd.1310

This Dissertation is brought to you for free and open access. It has been accepted for inclusion in Dissertations and Theses by an authorized administrator of PDXScholar. Please contact us if we can make this document more accessible: pdxscholar@pdx.edu. 


\title{
A STUDY OF PRINCIPALS' LEADERSHIP BEHAVIOR \\ IN ONE SUBURBAN SCHOOL DISTRICT
}

\section{by}

DARLEEN HUBER-DILBECR

\begin{abstract}
A dissertation submitted in partial fulfillment of the requirements for the degree of
\end{abstract}

\author{
DOCTOR OF EDUCATION \\ in \\ PUBLIC SCHOOL ADMINISTRATION AND SUPERVISION
}

\author{
Portland State University \\ The University of Oregon \\ C) 1988
}


TO THE OFFICE OF GRADUATE STUDIES:

The members of the Committee approve the dissertation of Darleen Huber-Dilbeck presented April 26, 1988.

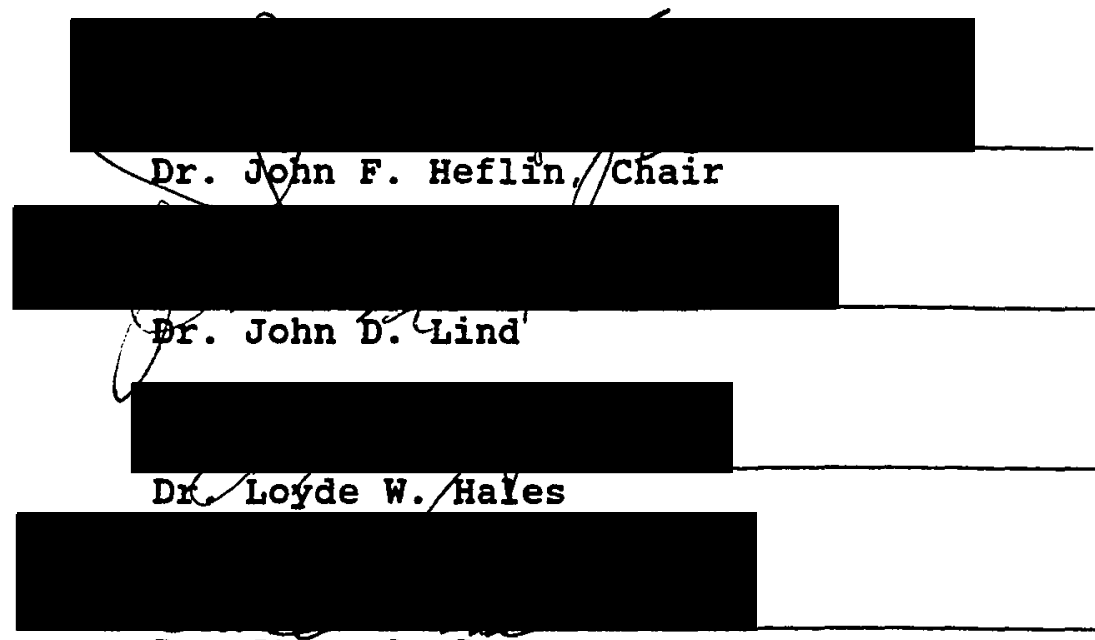

Dr. Stéve A. Brannan

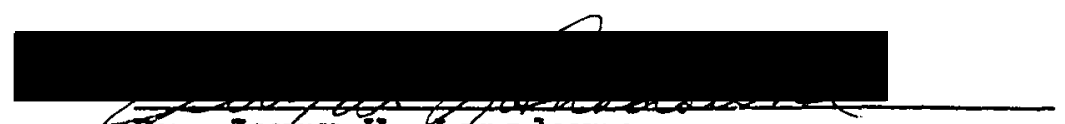

Dr. Jerry W. Lansdowne

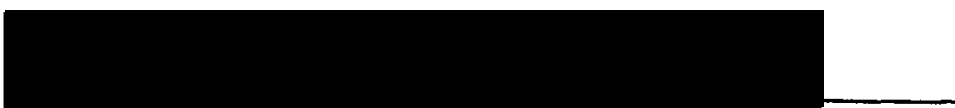

Dr. Daniel E. O'Toole

APPROVED:

Dr. Robert B. Everhart, Dean, School of Education, PSU

Dr. Richard A. Schmuck, Associate Dean, Div. of Education Policy and Management, $\varphi$ of 0

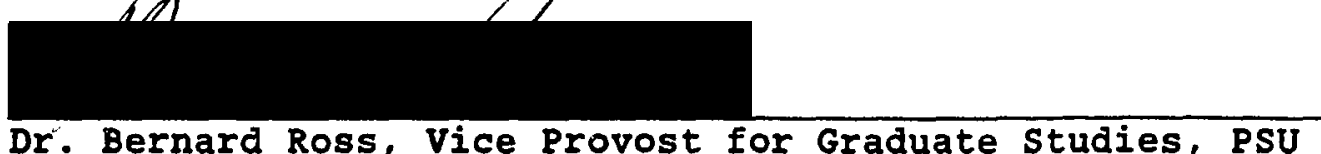


AN ABSTRACT OF THE THESIS OF Darleen Huber-Dilback for the Doctor of Education in Educational Administration and Supervision presented April 26, 1988.

Title: A Study of Principals' Leadership Behavior in One Suburban School District.

APPROVED BY THE MEMBERS OF THE DISSERTATION COMMITTEE:
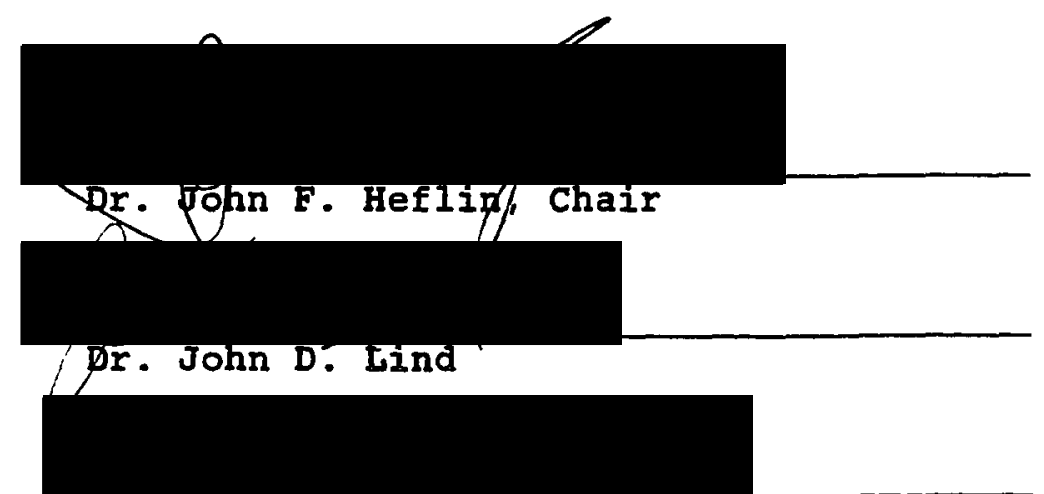

Dr. Loyde w. Háles

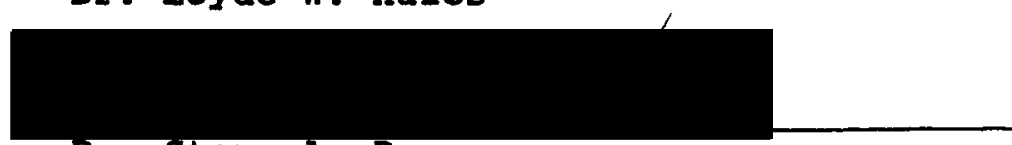

Dr. Steve A. Brannan
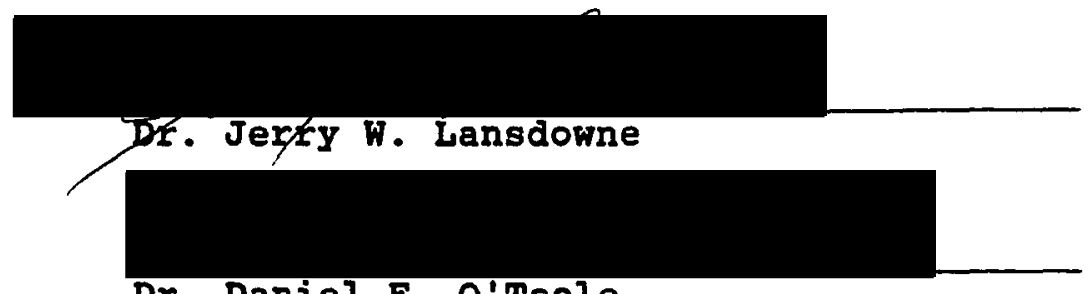

Dr. Daniel E. O'Toole

The purpose of this study was to investigate the leadership behavior of principals as perceived by the teachers and principals of one suburban school district. 
Research questions asked were: (1) Are there significant differences between the perceptions of principals and teachers concerning principals' leadership behavior on the twelve subscales of the LBDQ-XII? (2) Are there significant differences in viewing the leadership role when teachers' age, gender, teaching experience, level of training, or teaching assignment is considered?

This descriptive study invited 350 randomly selected teachers and all of the principals from 35 elementary, intermediate, and high schools in one suburban school district to participate on a voluntary basis. The perceptions of the principals' leadership behavior was measured by the twelve subscales of the Leadership Behavior Description Questionnaire--Form XII: Representation, Demand Reconciliation, Tolerance of Uncertainty, Persuasiveness, Initiation of Structure, Tolerance of Freedom, Role Assumption, Consideration, Production Emphasis, Predictive Accuracy, Integration, and superior Orientation. A biographical data questionnaire was also used.

Results obtained from the LBDQ-XII were displayed in tables with the twelve subscale means and standard deviations of tepaters and principals' perceptions of the principals' leadership behavior. The teachers' perceptions according to age, gender, years of teaching experience, 
levels of training, and teaching assignment subscale means and standard deviations were also calculated. A multivariate analysis of variance was performed for each of the teacher characteristics and the teachers and principals as independent variables. The subscales of the LBDQ-XII served as the dependent variables. All hypotheses were tested at the .05 level of significance.

The following conclusions were based upon the data collected and analyzed in the study. The perceptions of teachers of their principals' leadership behavior did not differ significantly according to gender, age, years of teaching experience, level of training, and teaching assignment. On all perceptions of twelve subscales tested, principals tended to rate themselves higher than the teachers. There were four areas in which principals and teachers differed significantly on the LBDQ-XII. They were Tolerance of Freedom, Consideration, Predictive Accuracy, and Integration.

Recommendations for further study using a larger population sample and different instruments to assess the areas in which principals and teachers differ in their perceptions of principals' leadership behavior were suggested. 


\section{ACRNOWLEDGEMENTS}

First, my greatest appreciation is extended to my husband Lloyd, all of my children, and my special friends, Jaci Nichols, Hal Nichols, and Charles Deemer, who have been an endless source of love and encouragement throughout $\mathrm{my}$ doctoral program and thesis writing. Without them, I could not have reached this educational goal.

My sincere thanks are extended to my dissertation committee for their valuable recommendations and support. Special mention must be made of John Heflin, my chairperson, and Loyde Hales who spent many hours of discussion and feedback sessions with me.

Finally, I wish to acknowledge my "first generation American" parents, Ratherine and Christ Huber, who imparted to me their philosophy of goal setting and hard work which made all this possible. 
TABLE OF CONTENTS

PAGE

ACRNOWLEDGEMENTS . . . . . . . . . . . . . . . . . iii

LIST OF TABLES. • . . . . . . . . . . . . . . . . . vii

CHAPTER

I INTRODUCTION . . . . . . . . . . . . . . 1

Statement of the Problem . . . . . . . 2

Hypotheses . . . . . . . . . . . 5

Delimitations of study . . . . . . . . 7

Limitations of Study . . . . . . . . 7

Definitions of Term. . . . . . . . . 7

Importance of stud . . . . . . . . . 10

II REVIEW OF LITERATURE • . • • . • • . • • • . 12

Introduction . . . . . . . . . . . 12

General Theories of Leadership . . . . . 12

Leadership Definition. . . . . . . . . 19

Approaches to Leadership Behavior. . . . . 24

Leadership Behavior of Principals. . . . 38

Leader Behavior Description

Questionnaire, Form XII (LBDQ-XII) . . . 45

Conclusions Regarding Leadership Behaviors 53

III METHODOLOGY. . . . . . . . . . . . . . 55

Introduction . . . . . . . . . . . 55

Research Design. . . . . . . . . . . 55 
Instrumentation. . . . . . . . . .

Data Collection Procedure. . . . . . . 61

Statistical Methodolgy . . . . . . . 63

summary. . . . . . . . . . . . . 64

IV IRESENTATION, ANALYSIS AND DISCUSSION

OF DATA . . . . . . . . . . . . 66

Sample Characteristics . . . . . . . 66

Analysis by Teachers' Gende. . . . . . . 68

Analysis by Teachers' Level of Training. . 70

Analysis by Teachers' Years of Experience. 75

Analysis by Teachers' Age. . . . . . . 78

Analysis of Teaching Levels. . . . . . . 81

Analysis of Principals' and Teachers'

Responses to the LBDQ-XII. . . . . . . 84

V SUMMARY, CONCLUSIONS AND RECOMMENDATIONS • . 89

Introduction . . . . . . . . . . 89

summary. . . . . . . . . . . . . 89

Findings . . . . . . . . . . . . 92

Conclusions. . . . . . . . . . . . 97

Recommendations. . . . . . . . 100

BIBLIOGRAPHY. . . . . . . . . . . . 105

APPENDIX A. . . . . . . . . . . . . . . . . . 116

APPENDIX B. . . . . . . . . . . . . . . . . . . . . 124

APPENDIX C. . . . . . . . . . . . . . 126 
APPENDIX D. . . . . . . . . . . . . . . . . 129

APPENDIX E. . . . . . . . . . . . . . . . 132

APPENDIX F . . . . . . . . . . . . . . . . . . 134 
I Independent and Dependent Variables... . . . 58

II Distribution of Respondents . . . . . . . . 67

III Respondents' Frequency Distribution by Gender . 68

IV Means and Standard Deviations of Teachers'

Responses Regarding Their Principals'

Leadership Behavior According to Gender. . . 69

V Respondents' Frequency Distribution by Level

of Training. . . . . . . . . . . . . . 71

VI Means and Standard Deviations of Teachers'

Responses Regarding Their Principals'

Leadership Behavior According to Level of

Training . . . . . . . . . . . . 73

VII Respondents' Frequency Distribution by Years

of Teaching Experience . . . . . . . . 76

VIII Means and Standard Deviations of Teachers'

Responses Regarding Their Principals'

Leadership Behavior According to Teaching

Experience . . . . . . . . . . . . . 77

IX Respondents' Frequency Distribution by Age. . . 79

$\mathrm{X}$ Means and Standard Deviations of Teachers'

Responses Regarding Their Principals'

Leadership Behavior According to Age of

Teachers . . . . . . . . . . . . 
viii

TABLE

PAGE

XI Respondents' Frequency Distribution by levels

of Teaching Assignment . . . . . . . . 82

XII Means and Standard Deviations of Teachers'

Responses Regarding Their Principals'

Leadership Behavior According to Level of

Teaching Assignment. . . . . . . . . . 83

XIII Means and Standard Deviations of Teachers and

Principals' Responses Regarding Principals'

Leadership Behavior. . . . . . . . . 86

XIV Analysis of Variance of Teachers and Principals'

Responses on Twelve Dimensions With Regard to

Principals' Leadership Behavior. . . . . . 
CHAPTER ONE

INTRODUCTION

School principals are considered the most important individuals in the administrative hierarchy of school systems. Recent emphasis has been on the leadership roles of principals in public schools (Edmonds, 1979; De Bevoise, 1984; Yukel, 1982). Research has shown that the role of the principal always has been and will continue to be one of the most influential leadership positions in American education (Cohen, 1983). Numerous articles and books cite research findings which indicate leadership of school administrators is a key characteristic of school effectiveness (Robinson, et al, 1982; Sergiovanni, 1984), and the leadership behavior of the designated school administrator is crucial in school success (Phi Delta Kappa, 1980).

The concept of leadership has been a topic of study and concern among scholars and practitioners in many fields; leadership is a phase of social process with the leader being responsible for the goals established by the group. Peters and Waterman (1982) stated that ordinary people who have outstanding leadership qualities make great leaders, while Bennis and Nanus (1985) believed that without effective leadership, organizations cannot be successful. 
In education, as in other fields, the major types of leadership employ psychological, sociological, behavioral, and contingency approaches (Lipham, Rankin, and Hoeh, Jr., 1985). The principal is the leader of his/her school, regardless of the approach that characterizes his/her leadership, and The National Association of Secondary School Principals describes a principal's responsibilites as:

A principal is responsible for all the activities that occur in and around the school building. It is his leadership that sets the tone of the school, climate for learning, level of professionalisin and morale of teachers and the degree of concern for what students may or may not become. (Wagstaff, 1973, p. 43)

successful leadership by principals is contingent upon acceptance, respect, and understanding by the teachers who work for them. One of the key functions of principals is to establish consensus among staff which leads to mutual goals, benefits, and successful school operations. One of the most important factors in achieving these goals is the principals' leadership behavior (Baldridge. 1971; Sergiovanni, 1984).

\section{STATEMENT OF THE PROBLEM}

The organization and operation of public schools under the leadership of the principal are as complex and varied as the turbulent age groups that are being educated in those schools. In recent years, educational leadership research has focused on the leadership behaviors of principals. 
A problem occurs when principals do not have sufficient knowledge of their leadership behaviors, and how those patterns of behavior are perceived by teachers who work under their supervision; this problem can work against successful accomplishment of leadership tasks required of prizlcipals in the schools. Hallinger, Mitman, and Murphy (1983) discussed current problems with research on educational leadership and concluded that more work is needed on specific practices and behaviors of school principals.

The process of successful execution of decisions depends upon a positive relationship between principals and teachers. Consequently, there is a need for teachers to communicate their perceptions of principals' leadership behaviors to their principals. Similarly, principals must be aware of behaviors that either help or hinder the accomplishment of the school's goals. Barnard (1938) noted that the leader's knowledge of how his/her followers perceive his/her behavior is one of the most important aspects of leadership.

Another problem is that systematic sharing of perceptions of leadership behavior between administators and staff in schools is often lacking since schools are loosely coupled (Anderson, 1982). Principals often find themselves losing their lines of communication, supply of information, and support, leaving them ineffective (Ranter, 1979). To 
avoid this situation, principals must make certain that their staff is sufficiently involved and informed. Hollander (1978), in discussing this crisis of leadership, called the lack of leadership communication "existential alienation" (p. 285). He stressed the need for followers to have a basis for believing they know what is happening in their organization; thereby remaining a part of it, instead of removing themselves psychologically from the organization. Hollander suggested that this need is satisfied by providing administrators with teachers' perceptions of their principals' leadership behavior and their principal's perceptions of his/her behavior. This information can be beneficial to school district administrators as they work toward implementing school goals.

The purpose of this study was to investigate the perceptions of a suburban school district's teachers and principals concerning the leadership behavior of the principals. To measure leadership behavior, the study utilized the twelve subscales of the Leader Behavior Description Questionnaire-Form XII (LBDQ-XII) developed by the Personnel Research Board located at ohio state University (stogdill, 1963). 


\section{HYPOTHESES}

The Leader Behavior Description Questionnaire, Form XII (LBDQ-XII) with its twelve dimensions provided the dependent variables to give data for Question one and Two. The following hypotheses were formulated for Question one: Are there significant differences as measured by the twelve subscales of the LBDQ-XII in the perceptions of principals' leadership behavior when the teachers' gender, levels of training, years of teaching, age, or level of teaching assignment is considered?

Hypothesis 1: Teachers' perceptions of the leadership behavior of their principals, based on the LBDQ-XII subscales, do not differ according to the gender of the teacher.

Hypothesis 2: Teacher's perceptions of the leadership behavior of their principals, based on the LBDQ-XII subscales, do not differ according to the levels of the teachers' training. The specific educational levels of teachers' training were: Bachelor's Degree, Bachelor's Plus, Master's Degree, and Master's Plus.

Hypothesis 3: Teachers' perceptions of the leadership behavior of their principals, based on the LBDQ-XII subscales, do not differ according 
to the teaching experience of the teachers.

The three levels of teaching experience were 1-3

years, 4-9 years, and 10 years and over.

Hypothesis 4: Teachers' perceptions of the

leadership behavior of their principals, based

on the LBDQ-XII subscales, do not differ according

to the age of the teachers.

The teachers' ages were categorized into Gould's '

(1978) career stage groupings of trial, stabilization, and maintenance stages.

Hypothesis 5: Teachers' perceptions of the

leadership behavior of their principals, based

on the LBDQ-XII subscales, do not differ according

to the levels of teaching assignment of the teachers.

For Question Two: Are there significant differences

between the perceptions of principals and teachers

concerning principals' leadership behavior as measured by

the twelve subscales of the LBDQ-XII, the following

hypothesis was formulated:

Hypothesis 6: Teachers and principals' perceptions of the leadership behavior of the principals, based on the LBDQ-XII subscales, do not differ. 


\section{DELIMITATIONS OF STUDY}

This study involves schools in one Pacific Northwest suburban school district. At the time of data collection, this district included 35 schools with a predominately white student population of $22,084,35$ principals, and 1,337 teachers who were also predominately white.

\section{LIMITATIONS OF STUDY}

A Iimitation of the study is that data were collected from only one suburban school district. Another limitation is that the teachers and principals in this sample represented the middle and upper-middle income population.

\section{DEFINITIONS OF TERMS}

The following are definitions of major terms used in this study:

1. School: the schools in the school district that enroll students in grades $\mathrm{R}-12$. Elementary schools includes grades 1 through 6 ; the intermediate schools include grades 7 through 9; and the high schools include grades 10 through 12 .

2. Principal: the designated person responsible for the management and supervision of an elementary, intermediate, or secondary school in 
3. Teacher: the assigned teacher in an elementary, intermediate, or secondary school responsible for instruction in the school district.

4. Leadership behavior: interpersonal

influence, exercised in situations and directed through the communication process, toward the attainment of a specified goal or goals. Leadership behavior involves the transaction between the leader and the follower seeking to satisfy human needs and expectations. For this study, it is the perceptions of a principals' leadership behavior as measured by the twelve dimensions of the LBDQ-XII. The leadership behaviors are defined by the LBDQ Form XII subscales.

(1) Representation: the leader speaks and acts as the representative of the group.

(2) Demand Reconciliation: the leader reconciles conflicting demands and reduces disorder in the group.

(3) Tolerance of Uncertainty: the leader is able to tolerate uncertainty and postponement without anxiety or upset.

(4) Persuasiveness: the leader uses persuasion and argument effectively and exhibits strong convictions. 
(5) Initiation of Structure: the leader clearly defines his/her own role and lets followers know what is expected of them.

(6) Tolerance of Freedom: the leader allows followers scope for initiative, decision, and action.

(7) Role Assumption: the leader actively exercises the leadership role rather than surrendering leadership to others.

(8) Consideration: the leader regards the comfort, well-being, status, and contributions of followers.

(9) Productive Emphasis: the leader applies pressure for productive output.

(10) Predictive Accuracy: the leader exhibits foresight and ability to predict outcomes accurately.

(11) Integration: the leader maintains a closely knit organization and resolves intermember conflicts.

(12) Superior Orientation: the leader maintains cordial relations with superiors, has influence with them, and strives for higher status. 


\section{IMPORTANCE OF THE STUDY}

Recent research in education has determined that the leadership behavior of the designated school administrator is crucial in determining school success (Phi Delta Rappa, 1980). The educational leadership of the school administrator is a critical characteristic of school excellence (Robinson and Block, 1982). However, the research has not focused on the perceptions of principals and their teachers with regard to the principals' leadership behavior: such a focus could help principals learn or unlearn behaviors for more effective leadership. Vroom (1977) stated that people in leadership positions are capable of increasing their effectiveness, and data gathered in this study adds to the information base of leadership behaviors considered important by teachers and principals. Principals may have a perception of their leadership behaviors that is not in agreement with how the teachers perceive those same behaviors.

Blank, in a paper presented at the annual meeting of the American Educational Research Association in San Francisco, April, 1986, pointed out the complexity of principal leadership research in the 1980's as it "cross cuts the educator-administrator distinction". Blank referred to a recent study by Daresh and Liu of principal 
instructional leadership behavior which used a questionnaire that contained five scales:

Staff development, teacher supervision and evaluation, instructional facilitation, resource acquisition and building maintenance, and student problem resolution" (Blank, 1986).

Teachers of the $1980^{\prime}$ 's have leadership expectations of their principals, and since the recent educational research in administration has been emphasizing the crucial role of the principal as a leader, it is timely to study the leadership behaviors of principals as perceived by both their teachers and the principals themselves. Similar research has been conducted and provided guidelines in this study (Ali, 1984; Allred, 1980; Daniels, 1980; Klein, 1980). Because the suburban school district considered here is undergoing major changes, this study should provide helpful information on how teachers and administrators view the leadership behavior of principals, information which can aid in the implementation of necessary changes. A knowledge of these educational leadership behaviors can provide "the currency used by a principal to move people and other resources toward achieving school goals" (Hallinger, Mitman, \& Murphy, 1983, p. 3021. 


\section{CHAPTER II \\ REVIEW OF THE LITERATURE}

\section{INTRODUCTION}

This chapter begins with a review of the literature concerning theories of leadership. The first concern was that without this background, the search for a definition of leadership would lack direction since the term has a wide assortment of interpretations. Another concern was to find what the literature said about the development of various approaches to leadership behavior and the leadership behavior of principals. After this examination, the literature of the LBDQ-XII was reviewed as the instrument used in many of the studies conducted on principals' leadership behavior.

\section{GENERAL THEORIES OE LEADERSHIP}

Theories and observations about leadership are as old as the history of man. As man developed to the point where he had to organize and manage his resources through group effort, ancient records began to record the activities of the group following a leader. The Christian Bible, the Islamic Roran, and the writings of Buddha are examples of a religious leadership theory. Later Machiavelli, in the 
Renaissance period, presented a political leadership theory. Ancient philosophers such as Socrates, Aristotle, and Plato argued that ideal leaders would themselves be philosophers (Misumi, 1985). Although the function of leaders has been recognized since ancient times, the formal study of leadership, particularly in scholarly publications devoted to it, is more recent.

Before discussing general leadership theory, it is important to examine leadership philosophy. Many observers question whether a body of knowledge exists that would allow a philosophical treatment of leadership; and if it does, they ask, what is the payoff? Hodgkinson (1983) suggested that the chief gain of such a philosophy "for the practitioner is power and for the theoretician, comprehension" (p. 228). Ordway Tead (1935) stated that "at the bottom our professional life is meaningless unless each works through to a philosophy which sees human dignity and significance as the essential criteria" (p. 20).

In 1934 Bogardus discussed the problem of leadership and went on to explain leadership as "personality in action" (p. 3). Leadership, he argued, involves the interaction of individual traits with group traits and this interaction determines a course of action. It is a group phenomenon that seeks an individual's leadership direction in order to solve problems (Bogardus, 1934). 
Barnard studied organizations as a system of human

beings working cooperatively to contribute to the operation of the organization. He placed great emphasis on

leadership, which he believed was influenced by such

variables as the individual, a group of followers, and

existing conditions of the organization. He felt that a

leader must facilitate cooperative group action that is both

effective and efficient (Barnard, 1938).

Dimock (1958) expressed his own philosophy thus:

We have swung so far in the direction of science, however, that it would be healthy for us now to realize that administration is essentially one of the humanities. Administration is, or at least ought to be, wedded to subjects such as philosophy, literature, history, and art, and not merely to engineering, finance, and structure. That this need is already though belatedly being appreciated is evidenced by the decisions of large corporations, such as the Bell system, which recently have joined forces with the educational facilities of large educational institutions, such as those of the University of Pennsylvania. There mature executives are given executive development courses revolving around literature, the arts, and philosophy. And why not?

Administrators become increasingly human and philosophical, capable of planning ongoing programs which meet human needs and aspirations when they are unified by areas of knowledge and skill which stress man's humanity and his philosophical insights. (p. 5)

The nature of theory, like leadership philosophy, precedes and can influence a theory of leadership. Feigl (1951) defined theory as a "set of assumptions from which can be derived by purely logico-mathematical procedures, a larger set of empirical laws" (p. 182). He felt that 
scientific explanation should be employed whenever more specific statements were derived from more general or hypothetical assumptions. This definition became accepted and popular in educational administration literature as it removed some of the ambiguity that surrounds the term "theory". Rerlinger (1965) submitted this definition and purpose of theory:

A theory is a set of interrelated constructs, definitions, and propositions that presents a systematic view of phenomena by specifying relations among variables, with the purposes of explaining and predicting the phenomena. (p. 11)

Rnezevich (1975) offered a similar definition by calling theory a "cluster of interlocking and interactive concepts systematized into an abstracted intellectual pattern capable of interpreting generalizable trends and relationships" (p. 139).

In discussing the nature and purpose of theories in general, Bass (1960) pointed out that the aim of a theory is to understand a phenomenon through rational and empirical observations. Theory guides the investigations. A satisfactory theory begins to be modified almost as soon as it is concluded, and this is an ongoing process. With these general definitions of theory in mind, it is time to look at theories of leadership. Bennis suggested revisions of leadership theories in 1966. He felt a satisfactory theory must account for impersonal bureaucracy 
and rationality of measures, informal organization and

interpersonal relations, benevolent autocracy, job enlargement and employee-centered supervision, and participative management and joint consultation.

Burns (1979) saw leadership as a part of the dynamics of power and conflict which brings about social change. The roles of the leader and his/her followers are conceptually united and are involved in all processes of human development and political action. He stated that leaders must choose the group's objectives wisely, forecast the cost of the objectives, the ability to gain those objectives, and the degree of goal attainment that is satisfactory to the group members. Although Burns said leadership is measured by the satisfaction of human needs and expectation, he conceded that too little is known about leadership and that there is little agreement on its essence. He explained that:

Leadership over human beings is exercised when persons with certain motives and purposes mobilize, in competition or conflict with others, institutional, political, psychological, and other resources so as to arouse, engage and satisfy the motives of followers...Leadership, unlike naked powerwielding, is thus inseparable from followers' needs and goals. (p. 19)

Late in his career, Bass (1981) used the following definition of leadership in his theory: "the observed effort of one member to change other members' behavior by altering the motivation of the other members or by changing their 
habits" (p. 447). While discussing leadership theories and definition, Bass observed:

Theories of leadership attempt to explain either the factors involved in emergence of leadership or the nature of leadership and its consequences. One complex definition of leadership that has evolved...delineates effective leadership as interaction between members of a group that initiates, maintains, improves expectations, and the competence of the group to solve problems and attain goals. (pp. 26 \& 584)

In ending his discussion of the philosophy of leadership Hodgkinson (1983) observed that:

The quintessence of this philosophy of leadership can be expressed succinctly. Philosophy is nothing but marks on paper or vibirations in the air unless it roots itself in the values of a man and changes his life. It is the singular wonder of leadership that such a change in one man's life has the potential for changing other lives. Such power is awesome. (p. 228)

Misumi (1985) suggested a leadership theory that centers around the idea of basic group functions called the PM Leadership. He defined the two functions as follows: $P$ is Performance, which involves the function of problem solving and working toward goal achievement; and $M$ is Maintenance, which involves the maintaining and strengthening the group process itself. In addition to using the $\mathrm{PM}$ theory to study administrative leadership behavior. Misumi also studied the effect that PM leadership behavior of teachers had on their students.

Educational leadership theories have always borrowed and been influenced by the research, conceptual framework, 
and effects originating in business and industry (Synder and Anderson, 1987). Naisbitt (1982) pointed out that management asks workers to participate in determining what the pattern of work should be, while Rosabeth Moss-Ranter (1983) noted that managers are in open-ended positions and must envision accomplishments beyond the scope of their job in order to acquire power to carry out new programs. Lee Iacocca's (1984) observations contrasted the controlling behavior of Henry Ford with his own success in being able to delegate responsibilities to talented people.

Harold Geneens' (1984) book on leadership emphasized a cooperative problem-solving approach, requiring honesty, trust, open communications, and frank discussions about problem situations. Seven characteristics that define the contemporary effective leader were postulated as follows by Tichy and Devanna (1986):

1. Leaders identify themselves as change agents;

2. They are courageous;

3. They believe in people;

4. They are value-driven;

5. They are lifelong learners;

6. They can deal with complexity, ambiguity, and uncertainty; and

7. They are visionaries.

Peter F. Drucker (1985) stressed the similarity between schools, businesses, and labor unions. He observed 
that both do many of the same things, use the same tools, and encounter similar problems. The cry for leadership comes from society when it must encounter social and economic crises, and the issues leaders must deal with are becoming more and more complex.

The literature supports the thesis that philosophies and theories of leadership are a central part of leadership behavior. This understanding leads to the discussion of a definition of leadership which follows.

\section{LEADERSHIP DEFINITION}

One difficulty in leadership research is conceptually clarifying what leadership involves. There is, in fact, considerable disagreement concerning its meaning. The next objective in reviewing the literature, therefore, is to clarify the definition of leadership which Burns (1980) called "one of the most observed and least understood phenomena on earth" (p. 3). Campbell (1984) agreed with Burns and went on to add that "it is easy to recognize, hard to describe, difficult to practice, and almost impossible to create in others on demand" (p. 2).

Stogdill (1948) reviewed 125 studies of the characteristics of leaders. A summary of his review noted that:

1. Supported by uniformly positive evidence from ten 
of the studies surveyed is the conclusion that the average person who occupies a position of leadership exceeds the average member of his group to some degree in the following respects:

(1) sociability;

(2) initiative;

(3) persistence;

(4) knowing how to get things done;

(5) self-confidence;

(6) alertness to, and insight into, situations;

(7) cooperativeness;

(8) popularity;

(9) adaptability; and

(10) verbal facility.

2. Supported by uniformly positive evidence from fifteen or more of the studies surveyed is the conclusion that the average person who occupies a position of leadership exceeds the average member of his group in the following respects:

(1) intelligence;

(2) scholarship;

(3) dependability in exercising responsibilities;

(4) activity and social participation; and

(5) economic and socio-economic status. 
In the 1981 revised and expanded edition of stogdill's leadership book, Bass continued to review the studies on theories and models of leadership.

The qualities, characteristics, and skills required in a leader are determined to a large extent by the demands of the situation in which he is to function as leader. Cattell discussed leadership as representing interaction between the goals of the leaders and the goals and needs of the followers. Leadership facilitates the selection and achievement of the groups' goals (Cattell, 1951).

The leadership patterns of principals and their staff reactions were studied by Redfern in 1966 . He described directive behavior, guiding behavior, vacillating behavior, and appeasing behavior by principals, and the reaction of the staff to these behaviors. The aggressive and domineering actions of directive behavior met with resistance or acquiescence on the part of the staff. Guiding behavior was favorable to the staff and facilitated their work. Uncertainty on the part of the staff was the result of vacillating behavior, and the appeasing behavior made the staff resentful. Redfern concluded that the characteristics of good leadership are insight, personal security, sensitivity, mature behavior, flexibility, and personal fulfillment. Peters and Austen (1985) noted that leaders must pay attention to what is important and confront 
problems. By avoiding obvious problems, leaders lose their credibility.

The complexity of leadership was also acknowledged by Fiedler (1976); he analyzed leadership in terms of a least-preferred-co-worker scale. He defined leadership as:

An extremely complex interpersonal relationship which can only be exercised in groups in which people want to accomplish a common goal. (p. 2)

Pfeffer (1977) studied the ambiguity of leadership definition and measurement and whether it has discernible effects on organization. Cohen (1983) agreed with the complexity of defining leadership, while Dufour and Eaker (1987) said that the image of a principal as a transitional leader wanting "to seek new ways to empower teachers is ambiguous and paradoxical" (p. 80).

Other studies concluded that leadership implies some incongruence between the objectives of the leader and the led (Rochan, Schmidt and DeCotiis, 1975). Lipham and Hoeh (1974) found that there is considerable disagreement concerning the meaning of leadership and offered their own definition as

That behavior of an individual which initiates a new structure in interaction within a social system; it initiates change in the goals, objectives, configurations, procedures, inputs, processes, and ultimately the outputs of social systems. (p. 200) 
Doll (1972) saw school leadership as a function which requires

Human behaviors which help a school achieve its constantly changing purposes, some of which are oriented toward productivity or task-performance and others of which are oriented toward interpersonal relationships, within the schools' own social climate and conditions. (p. 17)

Some writers used the term leadership interchangeably

with other terms such as administration and management.

Thus, Landers and Myers (1977) wrote:

We believe that the trend is toward a view of leadership as an integral function of management and administration in the modern organization. The term management, in current usage, implies the inclusion of administrative functions as well as a leadership role. Similarly, educational administration, as it is practiced in the modern school system, also includes a leadership role and management functions as well as the traditionally defined administrative duties... We do not believe that the terminology used to describe the specialty is as important as effective performance of the role. ( $p$. iv.)

Throughout the literature, one finds ambiguity in the definition of leatership. Pfeffer (1977) said that an "analysis of the leadership process is contingent on the intent of the researcher" (p. 101), while Campbell (1977) asserted "the conceptualization of leadership cannot be divorced from the purpose for which it is considered". Principals and teachers, in order to function effectively, must understand that they are working together to provide an environment conducive to learning. Since the principal is a key person, a knowledge of what the 
administrator perceives as the functions of his/her position and how he/she behaves in the position of leadership, as compared to the staff's perceptions of his/her role and leadership behaviors, is necessary for an understanding of successful leadership. (Solomon, 1983; Persell, 1982)

Hodgkinson (1983) presented the following propositions to define leadership:

Proposition 6.4 The term leadership is an incantation for the bewitchment of the led. Proposition 6.41 Leadership is an event, not an attribute of a personality. It is a description given to a dynamic complex of action. Proposition 6.42 Leadership is the conjunction of technical competence and moral complexity... The leader should 1) know the task. 2) know the situation. 3) know his followership.

4. Know himself. (pp. 228-229)

The definition of leadership utilized in this study is that leadership involves a transaction between the leader and his/her followers for the satisfaction of human needs and expectations. In this study, leadership focuses on the behavior of principals as perceived by their teachers and the principals themselves as measured by the twelve subscales on the LBDQ-XII.

\section{APPROACHES TO LEADERSHIP BEHAVIOR}

The concept of leadership behavior has been the topic of study in such diverse fields as administration, business, economics, education, psychology, and philosophy. The four major themes that emerge from the study of leadership 
behavior can be called the psychological, sociological, behavioral, and contingency approaches. A review of the literature reveals considerable diversity in all four areas. No one theory is perfect. Campbell (1956) noted that theoretical concepts may be helpful in providing insight, but they do not give a prescription for what to do in everyday situations.

The earliest research on leadership focused on the study of traits of an effective leader and the environment which brought about leadership behavior. Later research centered on a behavioral approach which recognizes psychological and sociological factors as behavioral determinants (Lassey, 1971). The contingency approach emphasizes the structure of the task and the personal, organizational and contextual contingency variables (Lipham, Rankin, and Hoeh, Jr., 1985). Each of these four approaches enjoys a period of dominance. The next section of the literature review will summarize the psychological, behavioral, sociological, and contingency approaches to leadership behavior.

\section{The Psychological Approach to Leadership Behavior}

The psychological approach adheres to the belief that leadership centers on the elements of the human personality. The unique personality structure of the individual makes the leader different from others. Neither acquired knowledge 
nor training can produce leadership since the individual capacity for leadership develops in early childhood. Put another way, leadership is an intangible, subjective element of the individual (Brown, 1973).

This theory suggests that leaders are basically different from other people. The list of charismatic leaders who were followed because of their unusual qualities is long and includes John F. Rennedy, Charles de Gaulle, Franklin D. Roosevelt, Winston Churchill, Nasser, Adolph Hitler, and Martin Luther (Zeleznik, 1974). The viewpoint here is that leaders are born, not made, and that instinct is more important than training. Bogardus, in a study of great men (Bogardus, 1934), said that leadership is a consequence of heredity, social stimuli, and personality traits. There is still a tendency today to view school leadership in terms of the great principal who makes a substantial difference in the operation of the school because of his/her personality traits and qualities. Desirable traits have been studied in order to discover the common characteristics of leaders. Thurston in 1944 found that successful leaders scored high on a test of perception and card sorting. Using a machine called an interaction chronograph, Chapple and Donald (1946) found that supervisors in structured interviews scored high in initiative, dominance, speed of interaction, and adjustment to the interview situation. The Thematic Apperception Test 
was used by Henry (1949) to supplement interview and test data from 100 business executives, and he concluded successful executives were high in achievement drive, mobility drive, emotional alertness and activity, ability to organize unstructured situations, and tendencies to identify with superiors.

Stogdill (1948) examined 124 leadership studies in organization and experimental environments. He listed the personality traits necessary for leadership as capacity, achievement, responsiblity, participation, and situation awareness. He concluded:

A person does not become a leader by virtue of the possession of some combination of traits, but the pattern of personal characteristics of the leader must bear some relevant relationship to the the characteristics, activities, and goals of followers. Thus, leadership must be conceived in some terms of the interaction of variables which are in constant flux and change. (p.58)

stogdill's book on leadership was updated in the third edition in 1981 by Bass, and additional studies since 1948 pointed to personality traits necessary for leadership.

A review of the leadership literature by Mann (1958) concluded that a number of relationships exist between a leader and his/her personality, such as intelligence, general adjustment, dominance, and extroversion. Speicher (1971) said that the trait approach defines an administrator's effectiveness in terms of such personal attributes as knowledge and desirable personality factors. 
The psychoanalytical theory has been used to explain how crisis situations bring about the rise of charismatic leaders by creating unusual interactions in which the needs of the followers get fulfilled (Devries, 1977). However, numerous other studies have failed to find any consistent pattern of traits characterizing leaders, and this failure is attributed to such factors as inadequate measurement and an inability to describe leadership adequately (Gibb, 1954).

Early leadership research focused on the psychological and physical characteristics which differentiated the leader from the group, and it is not surprising that this approach proved to be ineffective. Tannenbaum, Weschler, and Massarik (1961) observed that leaders do not function in isolation but must deal with followers within a cultural, social, and physical contact.

The traits that a leader must possess should be relevant to the characteristics, goals, and activities of the group members in the organization (Rnezevich, 1975). These traits are as varied as the situations that will develop in the organization, and they will change as the groups' objectives change.

Bennis (1985) asked leaders what personal qualities they need to run their organizations, and they listed the qualities of persistence, self-knowledge, willingness to take risks and accept losses, commitment, consistency, and constant learning. The leader who can be an enthusiastic 
learner, who is open to new experiences and challenges, and who can learn from his/her own mistakes, may be the role model for the followers and become the great leader in his/her organization.

Lipham, Rankin, and Hoeh, Jr. (1985) contended that this approach is the "great person" view, which holds that leaders are born and not made, that nature is more important than nuture, and that instinct is more important than training.

The psychoanalytical theory of leadership developed the view that great leaders with personal qualities took command during times of crisis. Alone, it is not an adequate theory and should be used in relationship to the sociological, behavioral, and other dimensions of leadership in specific situations, rather than as a dominant theory seeking to differentiate leaders from nonleaders solely on personality traits.

The Sociological Approach to Leadership Behavio:

Dissatisfaction with the psychological approach caused a shift from studying the traits of the leader to the study of the leader in the context of the circumstances that gave him/her an opportunity to emerge. The sociological approach contends that leadership is determined by the requirements of the social system. It is also known by the term human relations approach, where skills are developed by an 
understanding of human relations and by constant practice (Griffiths, 1956). In this view, leadership is a product of relationships in social situations; in different situations a leader may be the follower. This approach maintains that leadership is determined by the requiremeni, of the social systems.

Sanford (1951), in his study on leadership, declared that there are "three basic and delineable factors in any leadership phenomena: (1) the leader, (2) the situation, and (3) the followers" (p. 158). At the same time, Cattell (1951) found that the two primary functions of leaders are to help the group decide on a goal and to find the means for achieving that goal. In this theory, the leader represents the dynamic interchange between the goals of the leader and the needs and goals of the group.

Gibb (1954) identified the following four elements involved in leadership:

1. The structure of the interpersonal relations within a group;

2. The group or syntality;

3. Characteristics of the total culture in which the group exists and from which the group members have been drawn; and

4. The physical conditions and the task with which the group is confronted. 
From his observations of the same groups as they performed six tasks, Gibb (1954) concluded the following:

Since individual personality characteristics are, by contrast, very stable, it is to be expected that group leadership, if unrestricted by the conscious hierarchical structuration of the group, will be fluid and will pass from one member to another along the line of those particular personality traits, which by virtue of the situation and its demands, become for the time being, traits of leadership. This is why the leader in one situation is not necessarily the leader, even in the same group, in another different situation. (p. 902)

Hemphill's study found that the degree of satisfaction of group members and feelings of cohesion correlated more highly with leadership adequacy than did other dimensions. He identified two dimensions, viscidity (the feeling of cohesion in the group) and hedonic tone (the degree of satisfaction of group members), that correlated more highly with leadership adequacy than did dimensions such as position, participation, satisfaction, and dependence of the group (Hemphill, 1949).

A study by Gross and Herriott (1965) concluded that staff performance was improved with the orientation of principals toward good human relations. Bass (1960) emphasized that the more difficult the problems are that face a group and block their goal attainment, the more necessary successful leadership becomes.

Rnezevich (1975) said that a leader is the product of his relations with individuals and his/her ability to get 
the followers what they want, and that the best leaders are those who know and fit their particular group the best. Pfeffer (1977) stated that leadership is a major topic in social and organizational psychology. While there is some agreement that it is related to social influence, there is more disagreement concerning maintenance of the group and performance of some task or activity. He said that leadership analysis reinforces a social construction that legitimizes the leadership role, provides belief in potential mobility for those not in the leadership role, and provides belief in individual control.

In the late 1970 's the individual group members had received more consideration, and the position that leadership was a product of relationships in social situations was no longer dominant (McRague, 1970). Bennis and Nanus (1985) stated that a leader must be a "social architect" who is the silent variable that "governs the way people act, the values, and norms that are subtly transmitted to groups and individuals" (p. 110-111). This type of leadership presents a shared interpretation of goals and generates a commitment to the primary organizational values and philosophy.

The Behavioral Approach to Leadership Behavior

This approach combines two factors as research shows 
that behavioral approach to leadership behavior recognizes

both psychological and sociological factors. It

has focused on significant behaviors that are used to

describe leader behavior and on the perceptions of these

described behaviors by staff members of the leader. The

behavioral phase dated "roughly from the late 1940 s to the

early 1960s" (Schriseheim, Tolliver, and Behling, 1978, p.

34). Halpin (1959) stated that that the behavioral approach

focused upon observed behavior and no a priori assumptions

are made that leader behavior in one group situation may be

repeated in other group situations. He also indicated that

the term leadership is used in an evaluative sense:

In ordinary parlance the term leadership is used in an evaluative sense. To say that a man displays leadership implies that this is good or effective leadership. But the evaluation of what the leader does is only one aspect... If a description of the leader on specific dimensions of behavior is an evaluation of the effectiveness and efficiency of that behavior and can be obtained independently, then we can ascertain to what extent each dimension contributes to favorable evaluation. (p. 12)

The focus of the literature has been on behavioral dimensions that can be used to describe and delineate leadership behavior. This has been confirmed by Brown

(1967) in his study of leadership:

Staff statements describing the leader behaviors of their principals are useful from which to draw inferences relative to the nature of leadership existing in the school. (p. 62) 
The behavioral approach assumes that one can learn something about leadership from the perceptions of staff and other leaders. Campbell (1957) pointed out that the weight of evidence from research leads to the conclusion that more can be learned about leadership by centering on leadership acts than upon leaders themselves.

Getzels and Guba (1957) saw administration as a hierarchy of relationships. They postulated that there were three leadership styles: nomothetic, idiographic, and transactional. The nomothetic style defines roles and expectations that will fulfill the goals of a system even at the expense of the indvidual. Effectiveness is what the nomothetic leader expects. The second, the idiographic style, is influenced by personalities and individual needs. The idiographic leader is more concerned with his/her personality and those of other people than with institutional needs. The transactional style is intermediate between these two and involves moving toward the nomothetic style under one set of circumstances and toward the idiographic style under another set of circumstances. The transactional leader recognizes the importance of the institutional goals, but tries not to violate individual personality while achieving those goals.

Lipham and Rankin (1982) found that a single leadership style is ineffective and described a leadership theory that included structural, facilitative, supportive, 
and participative dimensions. It is important that a principal use one, a combination, or all of these dimensions, depending upon the problem that calls for his/her leadership behavior.

The concept of observable leader behaviors having an effect on subordinates was determined by Davis and Luthans (1979) as

... a cue to evoke the subordinates' task behavior. The subordinate's task behavior in turn can act as a consequence for the leader which, in turn, reinforces, punishes, or extinquishes the leader's subsequent behavior... The consequences for the subordinate's behavior may be related to the leader's subsequent behavior, the work itself, and its outcomes, or other organization members. (p. 239)

The PM theory of leadership discussed by Misumi (1985) used the early studies of leadership behavior by stogdill (1974), Lippitt and White (1943), Gibb (1969), and Bass (1981) to provide a background for understanding the theory. He concluded that the performance and naintenance conceptualization is a group phenomenon, is precise, contains no transcendental social values, allows for two dimensions of leadership, and is a functional scientific concept that is easy to use in experimental and field studies. 
The Contingency Approach to Leadership Behavior

Lipham, Rankin, and Hoeh, Jr. (1985) discussed four contingency approaches to leadership: path-goal relations, leadership adaptability, leader-group relations, and decision-leadership interaction. They define the contingency approach to leadership as:

The contingency approach to leadership analysis focuses on characteristics of both the leader and the situation, attempts to measure or estimate these characteristics, then provides the leader with useful behavioral guidelines based on various combinations of personal and situational contingencies. Contingency theories not only highlight the interactive complexity of leadership phenomena, but also provide potential leaders with concepts for assessing various situations and for demonstrating leadership behaviors that are situationally appropriate. p. 63)

One contigency approach to leadership analysis is the path-goal theory, which suggests that the effects of leadership depend on the task structure (House, 1971). The directiveness of the leader, the structure of the task, and the satisfaction of the subordinates are related, and a leader's effectiveness in goal attainment depends on these situational variables.

The contingency approach is described as the approach used when the leader's personality and characteristics are matched to the group's personality and characteristics, and the goals of the group are reached by this arrangement. (Fiedler, 1976). Blake and Mouton's (1964 and 1982) 
managerial grid also emphasized a high emphasis on concern of group and leader interaction.

zierden (1980) stated that leadership behavior depended on the circumstances and was contingent on four aspects of the situation. These four aspects are the nature of the people being managed, the characteristics of the work itself, the relationships between manager and employees and among employees, and the manager's personality and preferred management style. The conceptual framework of zierden reflects a contingency approach with four questions that followers have, and leaders should use these as guides to appropriate and effective actions. These questions are: 1) Where am I going? 2) How am I to get there? 3) Who will I be when I arrive? 4) Can I feel good about myself in the process?

The decision-leadership interaction helps leaders decide which leadership style would be the best to use in certain situations, while the leadership adaptability contingency approach recognizes that leaders must be able to adapt to many different situations. Hersey and Blanchard's (1977) response to this demand was to develop an instrument that presented situations to be assessed by leaders and group members. Assessment center procedures were developed by Hersey (1982) and currently are among the most promising techniques available for identifying administrative and leadership potential (Lipham, Rankin and Hoeh, Jr. 1985). 
Some studies on leadership suggested that inherent qualities of an individual cannot produce a leader that is separated from the situation in which he is involved, while other studies suggested that the opposite is true. A situation cannot produce a leader from a person without leadership traits. The qualities of leadership need to be observed and studied. To be able to determine the different levels of effectiveness of leadership, different research tools become necessary.

\section{LEADERSHIP BEHAVIORS OF PRINCIPALS}

Historically, the role of school principals began in the mid-nineteenth century when industrialization brought a change from rural one-room schoolhouses to larger schools in towns and cities. The principal began as a head teacher or "principal" teacher who continued to teach in addition to planning, coordinating, and supervising the different grade levels in the school. By the early 1900's, the position of the principal teacher had become a full-time administrative position without teaching duties, and the role of today's principals was established (Gross and Herriott, 1965). An identification of the most important leadership qualifications of principals included performing the "critical and enduring functions" of staff development, maintaining good school/community relations, supervision of instruction, and office management practices (Blumberg and 
Greenfield, 1980). Therefore, upon reviewing the literature, the concept and definition of leadership and leadership behaviors were considered to be the next item to investigate.

Leadership behavior exhibited by principals has become increasingly important in educational research on school administration in the $70^{\prime} \mathrm{s}$ and $80^{\prime} \mathrm{s}$. Many of the early studies on effective schools identified the principal as a critical factor in effective schools, leading to research that defined leadership behaviors of effective school leaders (Blumberg and Greenfield, 1980; Brookover, 1979; Trump, 1972; Yukel, 1982).

The principal of a school has major responsibilities to make things happen through other people. The decisions he/she makes and his/her delegations of authority require leadership behavior in order to bring about optimum performance, so that the goals of the school, faculty, student body, and patrons of the community can be realized (Jarvis, 1969; Rnezevich, 1975). In an article on student achievement and leadership, Brandt (1987) said that research has found that teachers' perceptions of their principals' leadership are related to student academic achievement.

For Bennis (1987) the role of the principal is founded on authority which is positional and structural; on the other hand, leadership is personal, behavioral, and a set of learned and practiced skills. There are individuals 
who have authority but not leadership, and there are individuals who may not be in a position of authority who nonetheless are admired, trusted, and get things done. The ideal is to have both authority and leadership. In discussing leadership, Lipman and Hoeh (1974) stated that:

Everyone agrees that the principal should be the leader of the school... The valuation of leadership is concerned with the extent to which leadership is accorded a positive connotation in the American culture. The locus for leadership examines the nature and boundaries of the focal social system (the school) within which leadership occurs. The stages of leadership include analysis of the sequential steps that one takes as he exercises leadership over time. Frequency and potency of leadership involve the frequency with which the principal leads as well as the magnitude of his leadership acts. The outcomes of leadership examine the relationship of the many dimensions of leadership to measures of effectiveness, morale, climate, and achievement within the school. (p. 9)

The leadership role of a principal involves many

functions. Educational leadership, instructional

leadership, and administrativ' leadership of principals were summarized by Blank (1987) in his comments on recent

research

on high schools:

A common finding of these studies is the critical role of the principal as a leader in creating school conditions that lead to higher student academic performance--conditions such as setting high standards and goals, planning and coordination with staff, orientation toward innovation, frequent monitoring of staff and student performance, and involving parents and the community. (p. 1) 
How principals acquire leadership goals depends upon what a principal decides to do, when he does it, and the manner in which he will achieve the goals. How leaders choose to influence and direct their followers was described by Rnickerbocker (1948). The leader may use force, paternalism, bargaining, or mutual means in which the leader and followers share the same aims. Early research characterized three styles of leadership behavior as autocratic, democratic, and laissez faire. White and Lippitt (1968) define these styles as:

1. Authoritarian: All determinations of policies by the supervisor; techniques and activity steps dictated by the authority, one at a time, so that future steps were always uncertain to a large degree; the leader usually dictated the particular work task and work companion of each member; the dominator tended to be personal in his praise and criticism of the work of each member, remained aloof from active group participation except when demonstrating.

2. Democratic: All policies a matter of group discussion and decision, encouraged and assisted by the leader; activity perspective gained during discussion period, general steps to group goal sketched, and when technical advice was needed, the leader suggested two or more alternative procedures from which choice could be made; the members were free to work with whomever they chose, and the division of tasks was left up to the group; the leader was objective or fact-minded in his praise or criticism, and tried to be a regular group member in spirit without doing too much of the work.

3. Laissez-faire: Complete freedom for group or individual decision, with a minimum leader participation; various materials supplied by the leader, who made it clear that he would supply information when asked; he took no part in work discussion; complete non-participation of the leader: infrequent spontaneous comments on 
member activities unless questioned, and no attempt to appraise or regulate the course of events. (p.319)

Because the terms democratic, authoritarian, and laissez-faire have undesirable connotations, Getzels and Guba (1957) suggested that leadership styles be described as nomothetic, iaiographic and transactional. These were also discussed by Getzels and Guba in relationship to the sociological process of administrative leadership behavior. Another group of terms used to describe leadership style was used by Rnezevic (1975) when he said that leadership was conceived of as:

1. an attribute of personality (symbolic leadership) :

2. a status, title, or position recognized in a formal organizational chart (formal leadersiisol; and

3. a function or role perfomed in an organized group (functional leadership). (p.81)

Conrath (1987) described leadership styles as permissive, non-directive authoritative, authoritarian, and paternalistic-maternalistic. He said that leaders find the style that fits their particular strengths and values.

Morris and Bennett (1979) studied leadership styles in terms of task-oriented and person-oriented behaviors. In 12 areas of competency, teachers rated principals and other supervisory personnel on their supervisory behaviors. Their findings concluded that supervisors were more concerned for both task and people than their principals were. Rnickerbocker (1948) described four ways in which a 
principal may chose to lead his/her group: force, paternalism, bargaining, and mutual means. If the principal uses force, it can come from any source; but it usually comes by virtue of his/her position as the appointed leader. Paternalism employs the "Father knows best" technique, while bargaining includes "You help me and I'll help you". In the mutual means style, both the leader and the group share the same purpose, and force is not needed in order to move toward goals.

A principal is not a leader by virtue of his/her status. Leadership, as McNeil (1961) stated, is "a pattern of interpersonal relations and a manner of fulfilling certain roles of responsibilites" (p. 59). The manner in which a principal fulfills his/her duties involves many dimensions of skills, behaviors, and actions, all of which lead people who work for him/her to perceive him/her as having good or bad leadership behavior. The ability to vary behavior in accordance with the nature of the problems that are encountered forces a principal to adopt many roles. Good administrators recognize the wisdom of combined executive approaches to leadership and possess a sufficiently strong ego for implementing their decisions (George, 1983).

The significant problem of a principal's role and behavior as an educator when relating to teachers, and his/her role as an administrator when relating to the 
central office, was reviewed in 1965 by Bidwell and by Glassman in 1984. Both concluded that the roles could be grouped into the two categories of educator and administrator. But many authorities disagreed on the various roles of a principal. Some felt educational leadership is his/her primary function. Other roles were cited as well, including instructional leader, leader for change, and decision maker (NASSP, 1970).

Different leaders have different styles, and what the leader chooses to do, when he/she does it, and the manner in which he/she does it, comprise his/her leadership style. Whether the leadership style is called autocratic, democratic, laissez-faire, nomothetic, ideographic or transactional, the style affects the behavior of the group members. Different styles affect the productivity and quality of work. Democractic leadership results in greater productivity than laissez-faire leadership, according to White and Lippitt (1968); autocratic leadership leads to greater productivity than democratic leadership, although the quality of work is consistently better under democratic leadership than under autocratic leadership. Finally, Burns (1978) noted that "heroic leadership is not simply a quality or entity possessed by someone, it is a type of relationship between leader and led. A crucial aspect of this relationship is the absence of conflict" (p. 10). 
As an educational leader, the principal of a school has many roles to fulfill in meeting the goals of the school, staff, and community. The style in which a principal directs, guides, and coordinates the program within the school should provide the leadership needed to meet the demands of the constantly changing educational situations in the $1980^{\prime} \mathrm{s}$.

LEADER BEHAVIOR DESCRIPTION QUESTIONNAIRE-FORM XII

$$
\text { (LBDQ-XII) }
$$

Observed behavior of the leader has been accepted as a productive way of understanding leadership, and much of the research concerning the behavioral approach in the field of education was derived from concepts developed by Ohio state University using the Leader Behavior Description Questionnaire and the Leader Behavior Description Questionnaire-Form XII (LBDQ-XII) (Hemphill and Coons, 1957). Since these research tools for leadership behavior have been widely used in the United states and foreign sountries, samples of the research are listed below, which should suggest the range of usefulness of the multi-dimensional questionnaires in pinpointing leadership behaviors.

Halpin and Winer at Ohio state University utilized the behavioral approach in their research and found two dimensions of leadership to be significant in the 
description of leader behavior: initiating structure and consideration. They obtained these dimensions from a factor analysis of respunses to the Hemphill and Coons Leader Behavior Questionnaire (Hemphill and Coons, 1957).

Many studies have been conducted using the two dimensional or quadrant classification of leadership to find variables that are significantly and positively correlated with a principal's leadership behavior. Lipman and Hoeh, Jr. (1974) summarize some of the findings.

1. In a sample of New York schools, Croghan (1969) found that school principals who were high in both initiating structure and consideration were more frequently designated by teachers as leaders of the informal group within their schools than were principals who were low on the same two dimensions.

2. McGhee (1971) reported that in schools in New York where no formal grievances had been filed by the teachers, the principals had higher consideration scores than in schools where formal grievances had been filed.

3. In Alabama schools, Lambert (1969) found a direct positive, and significant relationship between the principal's leader behavior, as measured by the two dimensions of the LBDQ, and teacher morale as measured by the Purdue Teacher 
Opinionnaire.

4. Watson (1965) found that leadership behavior of the principal was related to the cohesiveness the teaching group.

5. Concern regarding the limits of administrative authority prevalent in formal organizations resulted in a study by Kunz (1973) of teachers' probable compliance with their principles' directives. The study indicated that there was a strong relationship between Initiating structure of the principals and the zone of acceptance of directives by teachers irrespective of the Consideration scores (p. 192)

Stogdill (1963), working on the theory that it wasn't reasonable to believe that two factors were sufficient to account for all the observable behaviors in leaders, revised the LBDQ to include assessment of leadership behavior along twelve dimensions, and the new form was called LBDQ-XII. The use of the LBDQ-XII in research on leadership behavior in education has been extensive in the United states and other countries. Studies have shown that leadership behaviors can be identified, and a variety of factors related to leadership problems can be examined satisfactorily by using the LBDQ-XII as the research tool. 
Studies using the LBDQ-XII have been used extensively in research on leadership behavior. Jacobs (1965) used the LBDQ-XII to measure the degree to which the number of curriculum innovations were associated with administrative leadership among 138 Michigan junior high principals and six select teachers in each school. His study found that one of the most important factors in instituting educational change is the leadership behavior of the principal.

Findings indicated that principals and teachers have a very different view of the support teachers are given by principals. McGee and Eaker (1978) surveyed administrators and teachers in Tennessee, and 95 principals reported that teachers were given instructional support for their programs. Of the teachers, $49 \%$ responded that they did not receive support and $75 \%$ complained that new ideas were not provided by their superiors.

The LBDQ-XII questionnaire has been used to study teacher morale, job satisfaction, and teacher stress. A summary of some of these research findings follows.

Daniels (1981) surveyed 273 elementary school teachers and 10 principals in 157 public schools in Chicago. He concluded that the leadership dimensions of tolerance of freedom, initiation of structure, role assumption, and consideration had a dominant influence on the perceptions of inner-city elementary school teachers with regard to job satisfaction. The variables of teachers' age and years with 
a particular principal also influenced the teachers' sense of satisfaction (Danie1s, 1981).

In a study of the relationships between value orientations, leader behavior, and effectiveness of secondary school principals, data was collected from 311 teachers and 33 principals in 33 secondary schools. The LBDQ-XII measured the principals' leadership behavior from two viewpoints while other instruments measured the effectiveness and value orientations. Relationships between the variables were investigated by computing Pearson product moment correlation coefficients. There was evidence to suggest that teachers who perceived their principals as being effective gave them high scores on the twelve subscales of the LBDQ-XII (Hefty, 1971).

Leadership behaviors of principals and the school climate at the secondary level was studied by Rrueger in 1984. Principals, students, and staff from 22 secondary schools in the Puget Sound area of Washington state provided data for the study. The mean scores of the subscales of the LBDQ-XII and the mean scores of the subscales of a school climate survey indicated that a significant relationship existed between the teachers' perception of a leader's role and the teachers' perception of satisfaction and productivity in a school.

Freestone (1987), in examining the relationship of department heads' leader behaviors and teachers' perceived 
commitment to the organization, found that the leaders' behaviors were significant predictors of teachers' commitment and role definitions.

Both leadership style and teacher morale were studied by Perry in 1980 and Devault in 1981, using the LBDQ-XII and the Purdue Teacher Opinionnaire. Devault's study was in 35 of Virginia's secondary schools with 270 teachers and 35 principals, and Perry's study was conducted in the junior high schools of a selected metropolitan district in Oklahoma. The major findings by both researchers were that, when all personal and school demographic variables were controlled, there were statistically significant relationships between leadership styles of principals and teacher morale. Generally, the higher the principals' leader behavior was rated, the higher the teachers' morale. Sims (1977) demonstrated that a leader's positive reward behavior will increase a subordinate's performance, and Davis and Luthans (1979) also determined that behavior of the leader reinforces, punishes, or extinquishes subordinates' behaviors.

Barnard (1983) and Chapman (1983) studied teachers' perceptions of principals' leadership behavior as it related to stress and job satisfaction. Both studies showed a significant relationship between teachers' perceptions of the principals' leadership behavior and levels of stress and job satisfaction. Rnoop (1981) also found in his study of 
1,812 elementary and secondary teachers that job satisfaction was related to the consideration dimension on the LBDQ. Blase, Dedrick, and strathe (1987) surveyed 168 teachers and found that there was a high degree of association between teacher satisfaction and frequency of Initiation of structure and Consideration.

Jacobs (1963) analyzed a sample of Michigan secondary school principals to ascertain whether leadership behavior of principals in schools high in education innovation differed from that of principals in schools low in innovation.

In 1980 , Allred studied the relationship between teacher morale and the principal's leadership style in secondary schools in Texas, using the LBDQ and PTO in a manner similar to Lambert's $1969 \mathrm{study}$. He found there was a significant positive relationship between teacher morale and a teacher's perception of the leadership style of the principal.

In Thailand, a study using the LBDQ-XII had 608 secondary teachers rate their 22 principals' leadership behavior. Teachers rated their principals low in the four areas of Representation, Demand Reconciliation, Predictive Accuracy, and Integration. Recommendations for more specific training in those areas were made to the Ministry of Education (Sukhabanij, 1980). 
In Baghdad City, Iraq, elementary principals' leadership behavior as perceived by themselves and their teachers was studied using the LBDQ-XII to collect the data from 200 teachers and 20 principals. No significant differences in perceptions with regard to sex of teachers were found on the twelve subscales. There were significant differences between teachers and principals' perceptions on the subscales of Role Assumption, Demand Reconciliation, and Tolerance of Uncertainty (Mahdi,1984).

In 1984, a leadership study in Kuwait used the LBDQ-FORM XII to study leadership behaviors. The study of 300 secondary school teachers and 30 secondary school principals found a significant difference between teachers' and principals' perceptions of leadership behavior in Demand Reconciliation, but no signifcant difference on the other subscales (Ali, 1984).

The study of leadership behavior continues to be an important topic for study in the field of education in foreign countries as well in the United States, and the LBDQ-XII has been the instrument used in many of these studies. Since this instrument has been used so extensively to provide data for leadership behavior, it was decided to use the LBDQ-XII in this research survey. 


\section{CONCLUSIONS REGARDING LEADERSHIP BEHAVIOR}

To serve as a basis for the study of principals' leadership behaviors as perceived by principals and teachers in one suburban school district, theories of general leadership were reviewed. A discussion of the leadership principles of Bogardus (1934), Dimock (1958), Hodginson (1983), and others that preceded these theories was presented.

Although the definition of leadership is ambigious, as indicated by Bass (1981), Lipham and Hoeh, Jr. (1974), Peters and Austen (1985), stogdill (1974, 1981), and others, this study chose leadership to mean a transaction between the leader and followers in order to satisfy human needs and goals.

Four approaches for analyzing leadership were described: the psychological, sociological, behavioral, and contingency approaches. For the purpose of this study, the behavioral approach was considered the method that was best suited to reaching an understanding of the perceptions of teachers regarding the leadership behavior of their principals. Research using the Leader Behavior Description Questionnaire and the Leader Behavior Description Form--XII was reviewed before considering the leadership behaviors of principals. 
The problem presented in Chapter I stated that there was a need in the suburban school district for principals and teachers to kno: their perceptions of the most important leadership behaviors of principals. The literature review supports the selection of the Leader Behavior Description Form XII as being an appropriate instrument for measuring the perceptions of principals and teachers. 
CHAPTER III

METHODOLOGY

INTRODUCTION

In the study of principals' leadership behavior in one suburban school district, survey research to obtain the perceptions of the teachers and principals was selected as the research method. The research design is presented in this chapter with the independent and dependent variables. The Leader Behavior Description Questionnaire-Form XII was selected as the survey questionnaire, and the reliability and validity of the instrument is given. The data collection procedures and statistical methodolgy are also reported.

\section{RESEARCH DESIGN}

The interrelations of sociological and psychological variables can be studied by survey research which uses samples from the population. The characteristics of the whole population can be inferred from the samples drawn from the population with remarkable accuracy and much less cost, less time involvement, and greater efficiency than other types of research. Extensive, rather than intensive data, is provided by survey research, and concentration is on 
people and their opinions, beliefs, attitudes, and opinions (Fowler, 1985 \& Rerlinger, 1973). The problem statement of the study identified that teachers and principals' perceptions of the principals' leadership behavior to determine the school's goals is crucial in successfully achieving those goals. The survey research provided the method of obtaining teachers' perceptions of principals' behavior. Teachers and their principals from each elementary, intermediate, and high school were asked to respond to the Leader Behavior Description Questionnaire Form XII and complete a demographic data sheet. The demographic data included gender, level of educational training, years of teaching experience, age, and level of teaching assignment.

This descriptive study took place in one suburban school district in a large metropolitan area and consisted of a predominately white, middle and upper-middle class population. Randomly selected, 350 teachers from the teaching staff of 35 elementary, intermediate, and high schools, and all 35 principals in the school district were invited to participate on a voluntary basis in the study. The school district approved the voluntary survey of teachers and principals with protection of confidentiality. There was no need for identification numbers on the LBDQ-XII questionnaire or the biographical data for purposes of this 
study; therefore, the respondents were unknown to the researcher.

The data from the survey were analyzed to determine if there were significant differences in the perceptions of the leadership behavior of principals by teachers when the independent variables of the teachers' biographical data were used. Also, the data from the LBDQ-XII were analyzed to find if there were significant differences between the principals' and teachers' perceptions concerning the leadership behavior of principals among the twelve dimensions covered by the questionnaire.

For the purpose of this study, the twelve subscales of the Leader Behavior Description Questionnaire-Form XII were identified as the dependent variables, and the information from the biographical data questionnaires were identified as the independent variables. They are listed in the following table. 
TABLE I

INDEPENDENT AND DEPENDENT VARIABLES

\begin{tabular}{ll}
$\begin{array}{l}\text { Independent Variables } \\
\text { (Questionnaire) }\end{array}$ & $\begin{array}{c}\text { Dependent Variables } \\
\text { (LBDQ-XII Subscales) }\end{array}$ \\
\hline Gender of Teacher & Representation \\
Level of Trainiug & Reconciliation \\
Years of Teaching Experience & Tolerance of Uncertainty \\
Age of Teacher & Persuasiveness \\
Level of Employment & Initiation of Structure \\
& Tolerance of Freedom \\
& Role Assumption \\
& Consideration \\
& Production Emphasis \\
& Predictive Accuracy \\
& Integration \\
& Superior Orientation \\
&
\end{tabular}




\section{INSTRUMENTATION}

The Leader Behavior Description Questionnaire- Form XII (LBDQ-XII) provides subscale scores in twelve factors that describe the leadership behavior of a supervisor. Hemphill and Coons (1957) developed the original Leader Behavior Description Questionnaire for the Personnel Research Board at Ohio state University. From a factor analysis of the responses to the LBDQ, Halpin and winer found two dimensions of leadership which were significant in the description of leadership behavior--initiating structure and consideration.

In 1963, stogdill revised the questionnaire to include twelve dimensions of leadership behavior. These subscales were defined in Chapter II and include the twelve dependent variables of this study. The LBDQ-XII, shown in Appendix A, consists of short statements, with a Likert-type response scale, assigned to the twelve subscales which assess leadership behavior. The items on the subscales are not comparable in number (See Appendix A). A high score on any one of the subscales indicates that the respondent answered that the dimension of the subscale behavior was associated with the principal. A low score indicates that the respondent answered that the dimension of behavior was not associated with the principal. 
The manual for the LBDQ-XII contains a table of Reliability coefficients; this table appears in Appendix B (stodgill, 1963, p.8). The reliability of the instrument was determined by a modified Ruder-Richardson Formula consisting chiefly of correlating each item with the remainder of the items in its subscale which produced a conservative estimate of subscale reliability. Dipboye, in reviewing the LBDQ-XII, stated that the internal consistency coefficients ranged from .38 to .91 , with most of them in the .70 s and $.80 \mathrm{~s}$, which showed good internal consistency. He mentioned Greene reporting test-retest reliability of several of the subscales with coefficients ranging between .57 and .79 (Buros, 1978). To test the validity of the LBDQ-XII subscales, Stodgill in 1969 used the items in the subscales and wrote scenarios with the help of a playwright. Motion pictures were made of actors in the role of leaders and workers, and observers used the LBDQ-XII questionnaire to describe the "leaders' behavior" of the actors. In analyzing the data gathered from these observers, the data showed no significant differences between actors playing the same role for any of the subscales. Since the roles were designed to portray the behaviors represented by the items in its respective subscale, and the same items were used by observers to describe the enactment of the role, it was concluded that the scales measured what they were purported to measure (stogdill, 1974). Dipboye (1978) wrote "that the 
LBDQ-XII appears to possess concurrent validity in that its scales have been found to correlate with the external criteria of job satisfaction and performance and are capable of distinquishing between persons displaying behaviors corresponding to the dimensions" (Buros, 1978, p.5).

The biographical data questionnaire was patterned after several that had been used in other doctoral studies at Portland State University and included the necessary questions to obtain the information needed to test the study's research hypotheses (Borquist, 1986, \& Scott-Miller, 1984). A copy is found in Appendix C.

To determine if the LBDQ-XII and data questionnaires were easily understood, and if instructions could be followed in responding to the two forms, a field test was conducted in early April, 1987. A sample of six teachers and two administrators who were not employed in the district to be surveyed was used. The results of the field test were used to make small changes in directions, and the biographical questionnaire was modified. Included in the letter was the estimated time that it took to complete the LBDQ-XII questionnaire.

\section{DATA COLLECTION PROCEDURES}

The sample of the suburan school district teachers and principals for this study consisted of each principal and ten teachers from 26 elementary schools (grades KG-6), six 
intermediate schools (grades 7-9), and three high schools (grades 10-12). The 350 teachers were randomly selected by a computer. Permission to conduct the study was obtained from the school district's Director of Elementary Schools, the Director of Secondary Schools, and the Director of Planning and Program Evaluation.

The LBDQ-XII questionnaire, biographical data questionnaire, a letter explaining the study and inviting their participation, and a self-addressed, stamped return envelope were mailed to the principals and teachers on April 23, 1987. The researcher felt that since the responses were voluntary, a better return would be gained by routing the questionnaires to the home addresses of the respondents and enclosing a bag of tea for them to enjoy while answering the questions. The letter explaining the study assured the respondents of confidentiality; there was no identification code on any of the information mailed. No names were requested on the questionnaires, and there was no need to make any effort to identify the respondents. The letter asked that the questionnaire be returned by May 10, 1987 (See Appendix $D$ for a copy of the letter).

During the second week of May, a follow-up letter (See Appendix E) was mailed, urging the principals and teachers who had not returned the questionnaire to please complete and return it immediately. Thirteen of the principals had returned the initial questionnaire. The researcher decided 
to include another copy of the LBDQ-XII questionnaire and not request background data from the principals. Because principals might infer that the background data could be used to identify them, it was hoped that deleting the biographical questionnaire would encourage them to respond.

\section{STATISTICAL METHODOLOGY}

The returns of the LBDQ-XII and biographical questionnaires were numbered as they were received. Frequency of responses and distribution of respondents were tabulated and displayed in tables. All responses were scored, and a data file containing the dependent and independent variailes was set up and analyzed to test the null hypotheses. The results were displayed in tables containing the following descriptive statistical data.

1. Frequencies and percentages for the levels of the variables measured by the biographical questionnaire.

2. Subscale means and standard deviations of teachers' perceptions of their principals' leadership behaviors.

3. Subscales means and standard deviations of teachers' perceptions regarding their principals' leadership behavior according to the gender of the teachers, level of training, years of teaching experience, age, and level 
of teaching assignment (elementary, intermediate, or secondary).

4. Subscale means and standard deviations of the principals' answers regarding their own leadership behavior.

The inferential statistical data analysis included:

1. A multivariate analysis of variance was performed separately for each of the following teacher characteristics: gender, level of training, years of teaching experience, age, and the level of teaching assignment. For each analysis, the twelve subscales of the LBDQ-XII served as dependent variables.

2. A multivariate analysis of variance, with teachers and principals as levels of the independent variable and the twelve subscales of the LBDQ-XII as the dependent variables, was performed.

3. For each significant multivariate analysis, a univariate analysis was performed on each of the LBDQ-XII dependent variables.

All hypotheses were tested at the .05 level of significance.

\section{SUMMARY}

Principals and teachers in a suburban school district were the sample in this study. They were asked to complete 
the LBDQ-XII questionnaire and a biographical data questionnaire. The descriptive statistical data analysis included the independent variables of the biographical questionnaire and the dependent variables of the LBDQ-XII subscales. Statistical methodology included the computation of the means, medians, standard deviations for subscales, and the total score for the LBDQ-XII. For each independent variable, the dependent variable scores were analyzed, using multivariate analysis of variance, followed by one way analysis of variance as needed. 
CHAPTER IV

PRESENTATION, ANALYSIS AND DISCUSSION OF DATA

\section{INTRODUCTION}

The data analysis of the research study of leadership behavior of principals in one suburban school district is. presented in this chapter. The sample is described in terms of size, distribution, gender, age, level of training, years of teaching, level of employment lelementary, intermediate, secondary or principals), and responses to the LBDQ-XII. Results are reported to furnish evidence for accepting or rejecting the six hypotheses posed in the problem statement.

\section{SAMPLE CHARACTERISTICS}

Letters, biographical questionnaires, and LBDQ-XII questionnaires were mailed to 350 teachers and 35 principals from 35 schools in a suburban school district. The 350 teachers were randomly selected from 1,337 teachers of 22,084 students in 26 elementary schools, six intermediate schools, and three high schools.

A $50 \%$ response rate to a survey is considered an adequate response, while a 60\% response rate is good and a 70\% response rate is considered very good (Babbie, 1973). Respondents to the questionnaire totalled 225 for a total 
return rate of $58 \%$. Of the 350 teacher questionnaires, 183 were returned after the first mailing and 22 were returned after a follow-up letter which resulted in a total of 205 responses; this was a teacher response rate of $59 \%$ of the 205 responses, three were eliminated due to incomplete data. A total of 35 questionnaires were mailed to principals; 14 were returned after the first mailing and six after a follow-up letter, for a total of 20 responses and a $57 \%$ rate of return. The percentages of responses for principals and teachers by grade levels are presented in Table II.

\section{TABLE II}

DISTRIBUTION OF RESPONDENTS

\begin{tabular}{lccc}
\hline $\begin{array}{l}\text { Categories of } \\
\text { Respondent }\end{array}$ & $\begin{array}{l}\text { Selected } \\
\text { Sample }\end{array}$ & $\begin{array}{l}\text { Responding } \\
\text { Sample }\end{array}$ & $\begin{array}{c}\% \\
\text { Returned }\end{array}$ \\
\hline Elementary Teachers & 260 & 143 & 55.0 \\
Secondary Teachers & 90 & 59 & 65.5 \\
Total Teachers & 350 & 202 & $57.7 \star$ \\
Principals & 35 & 20 & 57.1 \\
TOTAL & 385 & 222 & 57.6 \\
\hline
\end{tabular}

* Does not include three unusable returns

The biographical questionnaire for the teachers asked the respondents for their gender, level of training, years of teaching experience, age, level of training, and level of employment (elementary teacher, intermediate teacher, secondary teacher, or principal). The independent variables 
of the study consisted of these responses. The dependent variables of the study were comprised of the responses to the twelve subscales on the LBDQ-XII.

\section{ANALYSIS BY TEACHERS' GENDER}

Distribution of sample by gender, means, and standard deviations on the LBDQ-XII subscales by gender, and the MANOVA for gender are presented.

Teacher respondents were asked to indicate their gender. Responding to the questionnaire were 160 female teachers and 42 male teachers. Table III provides a summary of the distribution of male and female teachers responding to the study. The mean and standard deviations of the respondents by gender for subscales of the LBDQ-XII are presented in Table IV.

TABLE III

RESPONDENTS' FREQUENCY DISTRIBUTION BY GENDER

\begin{tabular}{|c|c|c|c|c|c|}
\hline \multirow[b]{2}{*}{ Gender } & \multicolumn{2}{|c|}{ Selected Sample } & \multicolumn{3}{|c|}{ Responding Sample } \\
\hline & Ereq. & $x_{0}=$ & Freq. & $\begin{array}{l}\text { of } \\
\text { Selected } \\
\text { Sample }\end{array}$ & $\begin{array}{l}\% \text { of } \\
\text { Respond. } \\
\text { Sample }\end{array}$ \\
\hline Female & 266 & 75.9 & 160 & 60.6 & 79.2 \\
\hline Male & 84 & 24.1 & 42 & 50.0 & 20.8 \\
\hline TOTAL & 350 & & 202 * & 58.0 & \\
\hline
\end{tabular}

* Does not include three incomplete questionnaires 
TABLE IV

MEANS AND STANDARD DEVIATIONS OF TEACHERS' RESPONSES REGARDING THEIR PRINCIPALS' LEADERSHIP BEHAVIOR ACCORDING TO GENDER

\begin{tabular}{|c|c|c|c|c|}
\hline \multirow[b]{2}{*}{ Subscales } & \multicolumn{2}{|c|}{ Male Teachers } & \multicolumn{2}{|c|}{ Female Teachers } \\
\hline & $M$ & SD & $M$ & SD \\
\hline Representation & 20.14 & 2.43 & 19.58 & 2.48 \\
\hline Reconciliation & 18.24 & 2.91 & 18.08 & 3.85 \\
\hline $\begin{array}{l}\text { Tolerance of } \\
\text { Uncertainty }\end{array}$ & 33.98 & 5.72 & 34.80 & 7.05 \\
\hline Persuasiveness & 36.12 & 5.54 & 35.12 & 6.99 \\
\hline $\begin{array}{l}\text { Initiation of } \\
\text { structure }\end{array}$ & 39.48 & 4.27 & 38.21 & 5.08 \\
\hline $\begin{array}{l}\text { Tolerance of } \\
\text { Freedom }\end{array}$ & 36.55 & 6.44 & 37.17 & 7.88 \\
\hline Role Assumption & 38.24 & 4.82 & 37.84 & 5.83 \\
\hline Consideration & 35.62 & 6.01 & 35.41 & 7.41 \\
\hline $\begin{array}{l}\text { Production } \\
\text { Emphasis }\end{array}$ & 32.79 & 5.80 & 31.94 & 6.59 \\
\hline $\begin{array}{l}\text { Predictive } \\
\text { Accuracy }\end{array}$ & 17.71 & 2.64 & 17.48 & 2.95 \\
\hline Integration & 17.33 & 3.17 & 17.11 & 4.59 \\
\hline $\begin{array}{l}\text { Superior } \\
\text { orientation }\end{array}$ & 36.02 & 6.47 & 35.24 & 5.98 \\
\hline
\end{tabular}


of the twelve subscales of the LBDQ-XII, both male and female respondents scored the principals' leadership behavior lowest in the area of Integration, with means of 17.33 and 17.11 , respectively. The highest score by female respondents for principals' 1eadership behavior, with a mean of 38.21 , was in the Initiation of structure subscale; male respondents also scored the Initation of Structure subscale highest, with a mean of 39.48 .

A multivariate analysis of variance was performed, with gender as the independent variable and the twelve subscales of the LBDQ-XII as dependent variables. The $F(12,189)$ value for the Wilks's lambda was $.940(p) .05)$; the hypothesis that male and female teachers do not differ in their mean perceptions of the leadership behavior of their principals as measured by the LBDQ-XII scales was not rejected. As an aid in identifying potential variables for future studies, a one-way analyses of variance for these dependent variables are summarized in Appendix F(1).

\section{ANALYSIS OF TEACHERS' LEVEL OF TRAINING}

Distribution of sample by teachers' level of training. means, and standard deviations of the LBDQ-XII subscales by level of training, and MANOVA for level of training are presented.

Bachelor's Degree, Bachelor's Plus, Master's Degree, and Master's Plus were the levels of training designated by 
the respondents' replies. Eleven teachers with Bachelor's Degrees, 75 with Bachelor's Plus, 27 with Master's Degrees, and 89 with Master's Plus responded to the questionnaire. Approximately $95 \%$ of the teachers had some graduate level preparation, with $57.5 \%$ possessing at least a Master's Degree. The most frequently reported level of trining was the Master's Plus. The data in Table $V$ were reported by the teachers responding to the survey.

TABLE V

RESPONDENTS' FREQUENCY DISTRIBUTION BY LEVEL OF TRAINING

\begin{tabular}{lcc} 
Level of Training & Frequency & $*$ \\
\hline Master's Plus & 89 & 44.1 \\
Master's Degree & 27 & 13.4 \\
Bachelor's Plus & 75 & 37.1 \\
Bachelor's Degree & 11 & 5.4
\end{tabular}

The means and standard deviations of the respondents by levels of training for the LBDQ-XII are given in Table VI. Respondents in all four levels of training rated their principals' behavior in Initiation of structure highest in their scoring: Bachelor's mean $=39.5 ;$ Bachelor's Plus mean = 37.7; Master's mean $=38.1 ;$ Master's Plus mean $=39.2$ The respondents also rated their principals' behavior lowest in the area of Integration in their scoring: Bachelor's mean = 
15.9; Bachelor's Plus mean $=16.8 ;$ Master's mean $=16.5 ;$

Master's Plus mean $=17.9$.

A multivariate analysis of variance was performed to test the second null hypothesis, using level of the teachers as the independent variable and the twelve subscales of the LBDQ-XII as the dependent variables. The $F(36,553)$ value for the Wilks's lambda was $.818(p) .05)$; the hypothesis that teachers of varying educational preparation do not differ in their mean perceptions of the leadership behavior of their principals as measured by the LBDQ-XII subscales was not rejected. As an aid in identifying potential variables for future studies, the one way analyses of variance of these variables are summarized in Appendix $F(2)$. 
TABLE VI

MEANS AND STANDARD DEVIATIONS OF TEACHERS' RESPONSES REGARDING THEIR PRINCIPALS' LEADERSHIP BEHAVIOR ACCORDING TO LEVEL OF TRAINING

\begin{tabular}{|c|c|c|c|c|}
\hline \multirow[b]{2}{*}{ Subscale } & \multicolumn{2}{|c|}{ BA Degree } & \multicolumn{2}{|c|}{ BA+ Degree } \\
\hline & $M$ & SD & $\mathbf{M}$ & SD \\
\hline Representation & 19.55 & 2.34 & 19.39 & 2.56 \\
\hline Reconciliation & 16.73 & 3.23 & 17.76 & 3.87 \\
\hline $\begin{array}{l}\text { Tolerance of } \\
\text { Uncertainty }\end{array}$ & 32.36 & 7.97 & 34.88 & 6.99 \\
\hline Persuasiveness & 34.46 & 5.17 & 34.09 & 7.11 \\
\hline $\begin{array}{l}\text { Initiation of } \\
\text { structure }\end{array}$ & 39.55 & 3.64 & 37.67 & 4.81 \\
\hline $\begin{array}{l}\text { Tolerance of } \\
\text { Freedom }\end{array}$ & 34.27 & 9.61 & 36.73 & 7.71 \\
\hline Role Assumption & 38.73 & 4.76 & 37.43 & 5.74 \\
\hline Consideration & 35.00 & 5.95 & 34.84 & 7.48 \\
\hline $\begin{array}{l}\text { Production } \\
\text { Emphasis }\end{array}$ & 34.91 & 7.48 & 31.36 & 6.76 \\
\hline $\begin{array}{l}\text { Predictive } \\
\text { Accuracy }\end{array}$ & 16.73 & 1.62 & 17.20 & 2.95 \\
\hline Integration & 15.91 & 2.34 & 16.76 & 3.63 \\
\hline $\begin{array}{l}\text { Superior } \\
\text { Orientation }\end{array}$ & 33.73 & 11.03 & 34.72 & 5.64 \\
\hline
\end{tabular}

The items on the subscales are not comparable in number. 
TABLE VI CONTINUED

MEANS AND STANDARD DEVIATIONS OF TEACHERS' RESPONSES REGARDING THEIR PRINCIPALS' LEADERSHIP BEHAVIOR ACCORDING TO LEVEL OF TRAINING

\begin{tabular}{|c|c|c|c|c|}
\hline \multirow[b]{2}{*}{ Subscales } & \multicolumn{2}{|c|}{ Master's } & \multicolumn{2}{|c|}{ Master's + } \\
\hline & $M$ & SD & M & SD \\
\hline Representation & 19.89 & 2.57 & 19.91 & 2.39 \\
\hline Reconciliation & 17.52 & 3.63 & 18.84 & 3.46 \\
\hline $\begin{array}{l}\text { Tolerance of } \\
\text { Uncertainty }\end{array}$ & 32.68 & 6.27 & 34.32 & 6.55 \\
\hline Persuasiveness & 34.86 & 7.83 & 36.65 & 5.98 \\
\hline $\begin{array}{l}\text { Initiation of } \\
\text { structure }\end{array}$ & 38.07 & 5.37 & 39.16 & 4.99 \\
\hline $\begin{array}{l}\text { Tolerance of } \\
\text { Freedom }\end{array}$ & 36.71 & 7.30 & 37.75 & 7.35 \\
\hline Role Assumption & 37.39 & 5.47 & 38.41 & 5.73 \\
\hline Consideration & 34.79 & 7.33 & 36.25 & 6.93 \\
\hline $\begin{array}{l}\text { Production } \\
\text { Emphasis }\end{array}$ & 33.68 & 4.64 & 32.17 & 6.50 \\
\hline $\begin{array}{l}\text { Predictive } \\
\text { Accuracy }\end{array}$ & 16.96 & 3.47 & 18.08 & 2.68 \\
\hline Integration & 16.50 & 4.56 & 17.85 & 4.91 \\
\hline $\begin{array}{l}\text { Superior } \\
\text { orientation }\end{array}$ & 34.96 & 6.12 & 36.33 & 5.19 \\
\hline
\end{tabular}




\section{ANALYSIS OF TEACHERS' YEARS OF EXPERIENCE}

Distribution of sample by teachers' years of teaching experience, means and standard deviations of the LBDQ-XII subscales by years of teaching experience, and MANOVA for years of teaching experience are presented.

The teacher sample was stratified according to years of teaching experience: 1-3 years, 4-9 years, and 10 years and over. Table VII provides a summary of the frequency distribution of the teachers' responses by years of teaching experience. Of the respondents, 55 had less than ten years of teaching experience. The rest of the 202 respondents, 147 teachers, had ten or more years of teaching experience. The questionnaire also asked the respondents to indicate how many years they had been teaching with the principal whose leadership behavior they were scoring on the LBDQ-XII. of the 202 replying, 162 had worked for their present principal one to three years, 38 had worked for their present principal four to nine years, and two had worked for their present principal for ten or more years. 
TABLE VII

RESPONDENTS' FREQUENCY DISTRIBUTION BY YEARS

OF TEACHING EXPERIENCE

\begin{tabular}{|c|c|c|c|c|}
\hline \multirow[t]{2}{*}{ Years } & \multicolumn{2}{|c|}{$\begin{array}{c}\text { Total } \\
\text { Teaching Experience }\end{array}$} & \multicolumn{2}{|c|}{$\begin{array}{l}\text { With Present } \\
\text { Principal }\end{array}$} \\
\hline & Frequency & $\%$ & Frequency & 8 \\
\hline 10 years and over & 147 & 73.0 & 2 & 0.2 \\
\hline 4-9 years & 45 & 22.5 & 38 & 19.0 \\
\hline $1-3$ years & 10 & 0.5 & 162 & 80.8 \\
\hline
\end{tabular}

The means and standard deviations of the repondents by years of teaching experience for the LBDQ-XII are presented in Table VIII. On the twelve subscales, the teachers with one to three years of experience had a high mean of 40.5 in the area of Tolerance of Freedom. The teachers with four to nine years of experience and ten years plus had high means of 37.6 and 38.7 , respectively, in the area of Initiation of structure. The lowest mean, 17.9, for teachers with one to three years of experience was on Predictive Accuracy. The lowest scale means for teachers with four to nine years and ten years plus teaching experience were on Integration: 16.5 and 17.3 , respectively. 
TABLE VIII

MEANS AND STANDARD DEVIATIONS OF TEACHERS RESPONSES REGARDING THEIR PRINCIPALS' LEADERSHIP BEHAVIOR ACCORDING TO TEACHING EXPERIENCE

\begin{tabular}{|c|c|c|c|c|c|c|}
\hline \multirow[b]{2}{*}{ Subscales } & \multicolumn{2}{|c|}{$1-3$ Yrs. } & \multicolumn{2}{|c|}{ 4-9 Yrs. } & \multicolumn{2}{|c|}{$10+$ Yrs. } \\
\hline & $\underline{M}$ & SD & $\mathbf{M}$ & SD & $M$ & SD \\
\hline Representation & 19.30 & 1.64 & 19.29 & 2.20 & 19.84 & 2.59 \\
\hline Reconciliation & 19.10 & 3.21 & 17.82 & 3.96 & 18.14 & 3.61 \\
\hline $\begin{array}{l}\text { Tolerance of } \\
\text { Uncertainty }\end{array}$ & 36.30 & 5.42 & 34.20 & 6.80 & 34.65 & 6.89 \\
\hline Persuasiveness & 36.80 & 4.39 & 33.76 & 6.95 & 35.71 & 6.72 \\
\hline $\begin{array}{l}\text { Initiation of } \\
\text { structure }\end{array}$ & 39.80 & 3.99 & 37.56 & 4.69 & 38.67 & 5.05 \\
\hline $\begin{array}{l}\text { Tolerance of } \\
\text { Freedom }\end{array}$ & 40.50 & 4.04 & 35.98 & 8.14 & 37.13 & 7.58 \\
\hline Role Assumption & 37.60 & 6.10 & 37.51 & 6.23 & 38.07 & 5.44 \\
\hline Consideration & 38.30 & 4.69 & 34.57 & 7.72 & 35.55 & 7.07 \\
\hline $\begin{array}{l}\text { Production } \\
\text { Emphasis }\end{array}$ & 33.00 & 3.16 & 31.89 & 6.94 & 32.13 & 6.46 \\
\hline $\begin{array}{l}\text { Predictive } \\
\text { Accuracy }\end{array}$ & 17.90 & 2.03 & 17.13 & 2.91 & 17.62 & 2.93 \\
\hline Integration & 18.00 & 1.94 & 16.47 & 3.97 & 17.31 & 4.54 \\
\hline $\begin{array}{l}\text { Superior } \\
\text { Orientation }\end{array}$ & 34.10 & 3.99 & 35.47 & 5.15 & 35.47 & 6.64 \\
\hline
\end{tabular}

The items on the subscales are not comparable in number. 
A multivariate analysis of variance was performed using levels of teaching experience as the independent variable and the 12 subscales of the LBDQ-XII as dependent variables. The $F(24,376)$ value for the Hilks's lambda for teaching experience was $.916(p) .05)$; the hypothesis that teachers with varying years of teaching experience do not differ in their mean perception of the leadership behavior of their principals was not rejected. As an aid in identifying variables for further studies, a univariate analyses are summarized in Appendix $F(3)$.

\section{ANALYSIS BY TEACHERS' AGE}

Distribution of sample by teachers' age, means and standard deviations of the LBDQ-XII subscales by age, and MANOVA by age are presented. The respondents were asked to give their ages to their nearest birthday. The sample had a mean age of 43.60 with a median age of 43.60 ; the distribution was symmetrical. The standard deviation was 8.94. The ages were categorized into Gould's (1979) three career stage groupings:

1. Trial stage: $22-30$ years,

2. Stabilization Stage: $31-44$ years,

3. Maintenance stage: 45 and over years.

Table IX shows the respondents' frequency distribution in the three categories. 
TABLE IX

RESPONDENTS' FREQUENCY DISTRIBUTION BY AGE

\begin{tabular}{lcc}
\hline Age Groupings & Frequency & Percent \\
\hline Maintenance: 45 years and over & 88 & 43.6 \\
Stabilization: $31-44$ years & 95 & 47.0 \\
Trial state: 22-30 years & 19 & 9.4 \\
\hline
\end{tabular}

The means and standard deviations of the respondents by age for the subscales of the LBDQ-XII are presented in Table $x$. The lowest mean scores on the subscales for the 22-30 age group and 31-44 age group was Predictive Accuracy, with means of 16.0 and 17.6 , respectively. In the 45 years and over age group, the lowest mean (17.6) was on the Integration subscale. The highest mean score for the 22-30 age group was 36.3 in the Tolerance for Freedom subscale. For the 31-44 age group and 45 years and over age group, the highest means were on the Initiation of structure subscale $(39.0$ and 38.3 , respectively). 
TABLE X

MEANS AND STANDARD DEVIATIONS OF TEACHERS' RESPONSES REGARDING THEIR PRINCIPALS' LEADERSHIP BEHAVIOR ACCORDING TO AGE OF TEACHERS

\begin{tabular}{|c|c|c|c|c|c|c|}
\hline & $22-30$ & Yrs & $31-44 Y$ & $r s$ & $45+Y r s$ & \\
\hline Subscales & M & $S D$ & $M$ & SD & $M$ & SD \\
\hline Representation & 18.74 & 1.63 & 20.28 & 2.40 & 19.25 & 2.49 \\
\hline Reconciliation & 16.58 & 4.54 & 18.16 & 3.68 & 18.40 & 3.40 \\
\hline $\begin{array}{l}\text { Tolerance of } \\
\text { Uncertainty }\end{array}$ & 33.84 & 7.12 & 34.15 & 7.05 & 35.33 & 6.42 \\
\hline Persuasiveness & 32.05 & 7.16 & 36.17 & 6.51 & 35.13 & 6.66 \\
\hline $\begin{array}{l}\text { Initiation of } \\
\text { structure }\end{array}$ & 36.26 & 4.20 & 39.04 & 4.85 & 38.33 & 5.09 \\
\hline $\begin{array}{l}\text { Tolerance of } \\
\text { Freedom }\end{array}$ & 36.68 & 7.18 & 36.90 & 8.28 & 37.26 & 6.94 \\
\hline Role Assumption & 34.42 & 5.92 & 38.41 & 5.27 & 38.15 & 5.75 \\
\hline Consideration & 33.84 & 7.81 & 35.49 & 7.17 & 35.77 & 6.97 \\
\hline $\begin{array}{l}\text { Production } \\
\text { Emphasis }\end{array}$ & 31.84 & 5.19 & 33.04 & 6.76 & 31.16 & 6.22 \\
\hline $\begin{array}{l}\text { Predictive } \\
\text { Accuracy }\end{array}$ & 16.00 & 3.00 & 17.62 & 2.81 & 17.76 & 2.87 \\
\hline Integration & 16.15 & 3.63 & 16.92 & 3.80 & 17.63 & 4.96 \\
\hline $\begin{array}{l}\text { Superior } \\
\text { orientation }\end{array}$ & 33.90 & 5.33 & 36.09 & 6.10 & 34.97 & 6.18 \\
\hline
\end{tabular}

The items on the subscales are not comparable in number. 
A multivariate analysis of variance was performed, using age of teachers as the independent variable and the 12 subscales of the LBDQ-XII as dependent variables. The $F(24,376)$ value for the Wilks's lambda for age groups was $.191(p) .05)$. The hypothesis that teachers of varying ages do not differ in their means perceptions of the leadership behavior of their principals was not rejected. As an aid in identifying variables for future studies, univariate analyses of variance of the teachers' responses regarding their principals' leadership behavior according to age groupings are presented in Appendix F(4).

\section{ANALYSIS OF TEACHING LEVELS}

Distribution of sample by levels of teaching, means and standard deviations of th LBDQ-XII subscales for levels of teaching, and MANOVA for the levels of teaching are presented.

The respondents were asked to indicate the level at which they were teaching. They were distributed as follows: Elementary Level (70.8\%); Intermediate Level (22.3\%); and Secondary Level (6.98). The information is presented in Table IX. 
TABLE XI

\section{RESPONDENTS' FREQUENCY DISTRIBUTION BY LEVELS OF TEACHING ASSIGNMENT}

\begin{tabular}{lcc}
\hline Level of Assignment & Frequency & $\%$ \\
\hline Elementary Level & 143 & 70.8 \\
Intermediate Level & 45 & 22.3 \\
Secondary Level & 14 & 6.9 \\
\hline
\end{tabular}

The means and standard deviations of the respondents by level of teaching assignment for the subscales of the LBDQ-XII are given in Table XII. For teachers at Grades $\mathrm{K}-6$ and Grades 7-9, the Role Assumption subscale had the highest means (38.1 and 37.4 , respectively); and their lowest mean scores were on the Integration subscale, with means of 17.3 and 16.5, respectively. The teachers at Grades 10-12 scored Role Assumption highest, with a mean score of 37.9 , and Predictive Accuracy lowest, with a mean score of 17.1 . 
TABLE XII

MEANS AND STANDARD DEVIATIONS OF TEACHERS' RESPONSES
REGARDING THEIR PRINCIPALS ' LEADERSHIP BEHAVIOR
ACCORDING TO LEVEL OF TEACHING ASSIGNMENT

\begin{tabular}{|c|c|c|c|c|c|c|}
\hline \multirow[b]{2}{*}{ Subscales } & \multicolumn{2}{|c|}{ Gr. $\mathrm{RG}-6$} & \multirow{2}{*}{$\frac{\text { Gr. } 7-9}{M}$} & \multicolumn{3}{|c|}{ Gr.10-12 } \\
\hline & $\mathbf{M}$ & SD & & SD & $\mathbf{M}$ & SD \\
\hline Representation & 19.69 & 2.48 & 19.73 & 2.08 & 19.51 & 3.58 \\
\hline Reconciliation & 18.10 & 3.82 & 17.98 & 3.48 & 18.71 & 2.59 \\
\hline $\begin{array}{l}\text { Tolerance of } \\
\text { Uncertainty }\end{array}$ & 34.64 & 7.13 & 34.33 & 5.57 & 35.50 & 7.19 \\
\hline Persuasiveness & 35.74 & 6.59 & 34.22 & 7.40 & 34.71 & 5.50 \\
\hline $\begin{array}{l}\text { Initiation of } \\
\text { structure }\end{array}$ & 38.81 & 4.94 & 37.82 & 4.99 & 37.14 & 4.60 \\
\hline $\begin{array}{l}\text { Tolerance of } \\
\text { Freedom }\end{array}$ & 37.02 & 7.81 & 37.09 & 7.45 & 37.07 & 6.08 \\
\hline Role Assumption & 38.10 & 5.66 & 37.38 & 5.74 & 37.86 & 5.25 \\
\hline Consideration & 35.35 & 7.27 & 35.84 & 7.04 & 35.29 & 6.38 \\
\hline $\begin{array}{l}\text { Production } \\
\text { Emphasis }\end{array}$ & 32.66 & 6.83 & 30.87 & 5.41 & 30.57 & 4.54 \\
\hline $\begin{array}{l}\text { Predictive } \\
\text { Accuracy }\end{array}$ & 17.69 & 2.98 & 17.11 & 2.75 & 17.14 & 2.18 \\
\hline Integration & 17.30 & 4.51 & 16.47 & 4.18 & 17.79 & 2.52 \\
\hline $\begin{array}{l}\text { Superior } \\
\text { orientation }\end{array}$ & 35.10 & 6.32 & 35.67 & 5.56 & 37.64 & 4.88 \\
\hline
\end{tabular}


A multivariate analysis of variance was performed, using teaching level as the independent variable and the 12 scales of the LBDQ-XII as dependent variables. The F(24,376) value for the Wilks's lambda for teaching level was .41I(p).05); therefore, the hypothesis that elementary, intermediate, and secondary teachers differed in their perception of the leadership behavior of their principals was not rejected. To aid in identifying potential variables for future studies, one way analyses of variance are provided in Appendix (F5).

\section{ANALYSIS OF PRINCIPALS AND TEACHERS' \\ RESPONSES TO THE LBDQ-XII}

Distribution of sample by responses of principals and teachers to the LBDQ-XII subscales, means, and standard deviations of the principals and teachers' responses to the LBDQ-XII, and MANOVA for the principals and teachers' responses for the $L B D Q-X I I$ are presented.

Principals and teachers were asked to respond to the LBDQ-XII. The distribution of teachers by level of employment was: 143 elementary teachers, 45 intermediate teachers, and 14 high school teachers with a total of 202 completed questionnaires. Twenty principals responded with 17 completing the background information sheets.

The means and standard deviations of the teachers and principals for the subscales of the LBDQ-XII are presented 
in Table XIII. The means of the teachers' responses were lower in all of the twelve subscales than the means of the principals' responses. The teachers scored Initiation of Structure highest, with a mean score of 38.5 , and the principals scored Tolerance of Freedom highest, with a mean score of 40.7 . The teachers' lowest score was Integration with a mean score of 17.2 ; and the principals scored Reconciliation lowest, with a mean score of 19.6 .

A multivariate analysis of variance was performed with teachers and principals as levels of the independent variable and the 12 subscales of the LBDQ-XII as dependent variables. The hypothesis that teachers and principals do not differ in their perceptions of the leadership behavior of principals was rejected. The $F(12,209)$ value for the Wilks's lambda for the teachers/principals' variable was $.003(p<.05)$. The null hypothesis was rejected. Following the rejection of the null hypothesis in the multivariate analysis of variance, univariate analyses of variance were performed. Table XIV summarizes the analyses of variance of the principal and teachers' responses regarding the leadership behavior of principals. Signficant differences were found on the i'ulerance of Freedom, Consideration, Predictive Accuracy, and Integration subscales; the means for teachers were lower than the means for principals in each case. 
TABLE XIII

MEANS AND STANDARD DEVIATIONS OF TEACHERS' AND PRINCIPALS' RESPONSES REGARDING

PRINCIPALS' LEADERSHIP BEHAVIOR

\begin{tabular}{|c|c|c|c|c|}
\hline \multirow[b]{2}{*}{ Subscales } & \multicolumn{2}{|c|}{ Teachers } & \multicolumn{2}{|c|}{ Principals } \\
\hline & $\underline{M}$ & SD & $\mathbf{M}$ & SD \\
\hline Representation & 19.69 & 2.47 & 19.80 & 2.31 \\
\hline Reconciliation & 18.11 & 3.67 & 19.55 & 2.26 \\
\hline $\begin{array}{l}\text { Tolerance of } \\
\text { Uncertainty }\end{array}$ & 34.63 & 6.79 & 34.95 & 4.83 \\
\hline Persuasiveness & 35.33 & 6.71 & 37.85 & 4.22 \\
\hline $\begin{array}{l}\text { Initiation of } \\
\text { structure }\end{array}$ & 38.48 & 4.94 & 39.90 & 3.87 \\
\hline $\begin{array}{l}\text { Tolerance of } \\
\text { Freedom }\end{array}$ & 37.04 & 7.60 & 40.70 & 4.67 \\
\hline Role Assumption & 37.92 & 5.63 & 40.05 & 4.30 \\
\hline Consideration & 35.46 & 7.13 & 40.55 & 3.52 \\
\hline $\begin{array}{l}\text { Production } \\
\text { Emphasis }\end{array}$ & 32.12 & 6.43 & 33.90 & 5.38 \\
\hline $\begin{array}{l}\text { Predictive } \\
\text { Accuracy }\end{array}$ & 17.53 & 2.88 & 19.75 & 1.37 \\
\hline Integration & 17.15 & 4.33 & 20.15 & 2.30 \\
\hline superior orientation & 35.40 & 6.08 & 36.85 & 4.51 \\
\hline
\end{tabular}

The items on the subscales are not comparable in number. 
TABLE XIV

ANALYSIS OF VARIANCE OF TEACHERS' AND PRINCIPALS' RESPONSES ON TWELVE DIMENSIONS WITH REGARD TO

PRINICPALS' LEADERSHIP BEHAVIOR

\begin{tabular}{|c|c|c|c|}
\hline Subscales & DE & $\begin{array}{r}\text { Sum of } \\
\text { squares }\end{array}$ & $\underline{P}$ \\
\hline $\begin{array}{l}\text { Representation } \\
\text { Between Groups } \\
\text { Within Groups } \\
\text { Total }\end{array}$ & $\begin{array}{r}1 \\
220 \\
221\end{array}$ & $\begin{array}{r}.209 \\
1330.171 \\
1330.378\end{array}$ & .853 \\
\hline $\begin{array}{l}\text { Reconciliation } \\
\text { Between Groups } \\
\text { Within Groups } \\
\text { Total }\end{array}$ & $\begin{array}{r}1 \\
220 \\
221\end{array}$ & $\begin{array}{r}37.534 \\
2799.331 \\
1836.865\end{array}$ & .087 \\
\hline $\begin{array}{l}\text { Tolerance of Uncertainty } \\
\text { Between Groups } \\
\text { Within Groups } \\
\text { Total }\end{array}$ & $\begin{array}{r}1 \\
220 \\
221\end{array}$ & $\begin{array}{r}1.879 \\
9706 \cdot 104 \\
9707.983\end{array}$ & .837 \\
\hline $\begin{array}{l}\text { Persuasiveness } \\
\text { Between Groups } \\
\text { Within Groups } \\
\text { Total }\end{array}$ & $\begin{array}{r}1 \\
220 \\
221\end{array}$ & $\begin{array}{r}115 \cdot 412 \\
9387.327 \\
9502.739\end{array}$ & .102 \\
\hline $\begin{array}{l}\text { Initiation of structure } \\
\text { Between Groups } \\
\text { Within Groups } \\
\text { Total }\end{array}$ & $\begin{array}{r}1 \\
220 \\
221\end{array}$ & $\begin{array}{r}36.941 \\
5182.176 \\
5219.117\end{array}$ & .212 \\
\hline $\begin{array}{l}\text { Tolerance of Freedom } \\
\text { Between Groups } \\
\text { Within Groups } \\
\text { Total }\end{array}$ & $\begin{array}{r}1 \\
220 \\
221\end{array}$ & $\begin{array}{r}243.829 \\
12007.883 \\
12251.712\end{array}$ & $.036 *$ \\
\hline
\end{tabular}

*Significant at the .05 level. 
TABLE XIV CONTINUED

\section{ANALYSIS OF VARIANCE OF TEACHERS' AND PRINCIPALS' RESPONSES ON TWELVE DIMENSIONS WITH REGARD TO PRINCIPALS' LEADERSHIP BEHAVIOR}

\begin{tabular}{|c|c|c|c|}
\hline Subscales & DE & $\begin{array}{r}\text { Sum of } \\
\text { squares }\end{array}$ & P \\
\hline $\begin{array}{l}\text { Role Assumption } \\
\text { Between Groups } \\
\text { Within Groups } \\
\text { Total }\end{array}$ & $\begin{array}{r}1 \\
220 \\
221\end{array}$ & $\begin{array}{r}82.501 \\
6729.683 \\
6812.185\end{array}$ & .102 \\
\hline $\begin{array}{l}\text { Consideration } \\
\text { Between Groups } \\
\text { Within Groups } \\
\text { Total }\end{array}$ & $\begin{array}{r}1 \\
220 \\
221\end{array}$ & $\begin{array}{r}472.325 \\
10451.049 \\
10923.374\end{array}$ & $.002 \star$ \\
\hline $\begin{array}{l}\text { Production Emphasis } \\
\text { Between Groups } \\
\text { Within Groups } \\
\text { Total }\end{array}$ & $\begin{array}{r}1 \\
220 \\
221\end{array}$ & $\begin{array}{r}57.736 \\
8864.949 \\
8922.685\end{array}$ & .223 \\
\hline $\begin{array}{l}\text { Predictive Accuracy } \\
\text { Between Groups } \\
\text { Within Groups } \\
\text { Total }\end{array}$ & $\begin{array}{r}1 \\
220 \\
221\end{array}$ & $\begin{array}{r}90.113 \\
1704.126 \\
1794.239\end{array}$ & $.001 *$ \\
\hline $\begin{array}{l}\text { Integration } \\
\text { Between Groups } \\
\text { Within Groups } \\
\text { Total }\end{array}$ & $\begin{array}{r}1 \\
220 \\
221\end{array}$ & $\begin{array}{r}163.406 \\
3868.793 \\
7853.279\end{array}$ & $.003 *$ \\
\hline $\begin{array}{l}\text { Superior Orientation } \\
\text { Between Groups } \\
\text { Within Groups } \\
\text { Total }\end{array}$ & $\begin{array}{r}1 \\
220 \\
221\end{array}$ & $\begin{array}{r}38.211 \\
7815.071 \\
7853.279\end{array}$ & .301 \\
\hline
\end{tabular}

*Significant at the .05 level. 
CHAPTER V

SUMMARY, CONCLUSIONS, AND RECOMMENDATIONS

\section{INTRODUCTION}

This chapter presents a summary of the research investigating whether significant differences exist between teachers and principals in their perceptions of principals' leadership behavior. A discussion summarizing the purpose, procedures, results, and conclusions are given. Recommendations for future research are also included in this chapter.

\section{SUMMARY}

In recent years, educational research has focused on the principal as the "leader" of the school. The purpose of this study was to determine if significant differences existed between perceptions of teachers and principals with regard to principals' leadership behavior. The study also looked at whether significant differences existed between teachers' perceptions of principal leadership behavior based on the variables of gender, levels of training, years of teaching, age, and level of employment.

Research questions asked were:

1. Are there significant differences measured by 
the twelve subscales of the LBDQ-XII in the perceptions of the principals' leadership behavior when the teachers' gender, levels of training, years of teaching, age, or level of teaching assignment is considered?

2. Are there significant differences between the perceptions of principals and teachers concerning the leadership behavior of principals as measured by the LBDQ-XII?

The LBDQ-XII questionnaire, developed by Stogdill, was determined to be a valid and reliable instrument. Stogdill revised the original Leader Behavior Description Questionnaire developed by Halpin and Winer to include twelve dimensions to analyze leadership behavior. stogdill's instrument has been used extensively for research into administrative leadership behavior. The twelve dimensions of leadership behavior measured by the questionnaire include: Representation, Demand Reconciliation, Tolerance of Uncertainty, Persuasiveness, Initiation of structure, Tolerance of Freedom, Role Assumption, Consideration, Production Emphasis, Predictive Accuracy, Integration, and superior orientation.

The following hypotheses were tested: Hypothesis 1: Teachers' perceptions of the leadership behavior of their principals, based on the LBDQ-XII subscales, do not differ according to 
the gender of the teacher.

Hypothesis 2: Teacher's perceptions of the leadership behavior of their principals, based on the LBDQ-XII subscales, do not differ according to the levels of the teachers' training. Hypothesis 3: Teachers' perceptions of the leadership behavior of their principals, based on the LBDQ-XII subscales, do not differ according to teaching experience of the teachers Hypothesis 4: Teachers' perceptions of the leadership behavior of their principals, based on the LBDQ-XII subscales, do not differ according to the age of the teachers. Hypothesis 5: Teachers' perceptions of the leadership behavior of their principals, based on the LBDQ-XII subscales, do not differ according to the levels of assignment of the teachers. Hypothesis 6: Teachers and principals' perceptions of the leadership behavior of the principals, based on the LBDQ-XII subscales, do not differ.

The sample for the study was comprised of 350 teachers and 35 principals from 35 schools in one suburban school district in the Pacific Northwest. Teachers' biographical data of gender, age, years of teaching experience, academic training, and level of teaching assignment were also 
collected. Treatment of the data included a multivariate analysis of variance. For each significicant multivariate analysis, a univariate analysis was used. All hypotheses were tested at the .05 level of significance.

\section{FINDINGS}

A sample of 350 teachers (266 females and 84 males) were mailed the LBDQ-Form XII and a biographical questionnaire; 160 female teachers (61\%) and 42 male teachers (50\%) responded for an overall response rates of 58\%. The highest percentage of respondents were at the secondary level with $66 \%$ of the teachers returning questionnaires. The percentage of elementary teachers responding to the questionnaire were 55\%. A total of $58 \%$ of teachers in the sample returned the questionnaire.

The findings of the study are summarized within the structure provided by the hypotheses in Chapter I.

Hypothesis 1: Teachers' perceptions of the leadership behavior of their principals, based on the LBDQ-XII subscales, do not differ according to the gender of the teacher. (p. 7)

In response to the twelve subscales of the LBDQ-XII both male and female teachers' mean scores were highest at the Initiation of structure and lowest at Integration. Table IV provides the means of the twelve subscales and shows the means scores for both males and females. In the multivariate analysis of variance, using gender of teachers 
as the independent variable and the scales of the LBDQ-XII as dependent variables, the hypothesis was not rejected at the .05 level of significance.

Hypothesis 2: Teacher's perceptions of the leadership behavior of their principals, based on the LBDQ-XII subscales, do not differ according to the levels of the teachers' training. (p. 7)

The respondents to the survey indicated a high number of teachers with more than a Bachelor's Degree of training. Only eleven of the teachers had a Bachelor's degree with 89 teachers who had a Master's + degree as displayed in Table X. Consistently, the teachers with a Master's + degree scored the leadership behavior of the principals on the twelve subscales of the LBDQ-XII higher than those teachers with a Bachelor's degree as shown in Table VI. The highest mean score of all four educational levels was the subscale of Initiation of structure and the lowest mean score was at the Integration level.

In the multivariate analysis of variance using levels of educational levels of training of the teachers as the independent variable and the scales of the LBDQ-XII as dependent variables, the hypothesis was not rejected at the .05 level of significance.

Hypothesis 3: Teachers' perceptions of the leadership behavior of their principals, based on the LBDQ-XII subscales, do not differ according to teaching experience of the teachers. (p. 8)

Respondents to the question of the levels of teaching experience in the survey reveal that most of the teachers 
had more than ten yaars of teaching experience. Only 5 had less than ten years as shown in Table VII. Looking at the means of the twelve subscales on the LBDQ-XII, there is a chance difference that the scores on the subscales of the questionnaire vary with the teachers with one to three years of experience rating their principals' leadership behavior highest in Tolerance of Freedom and those with four to nine years and ten years plus experience rating the subscale of Initiation of structure the highest. The teachers with one to three years of experience scored Productive Accuracy as the lowest score and those with four years or more experience rated Integration as the lowest subscale.

In the multivariate analysis of variance, using the difference in the years of teaching experience of the teachers as the independent variable and the scales of the LBDQ-XII as dependent variables, the hypothesis was not rejected at the .05 level of significacs.

Hypothesis 4: Teachers' percepticns of the leadership behavior of their princj.pals, based on the LBDQ-XII subscales, do rot differ according to the age of the teachers. (p. 8)

In determining whether or not the difference in teachers' ages would impact the way they perceive the leadership behavior of their principals, it was found that the lowest mean scores on the subscales by the 22-30 age group and 31-44 age group was Predictive Accuracy with Integration scoring the lowest mean in the $45+$ age group. 
The highest mean scores were: for the 22-30 age group in the Tolerance of Freedom subscale and for the $31-44$ age group and 45+ age group in the Initiation of structure subscale. As Table IX indicates the number of respondents in the 22-30 age group numbered 19 as compared to 96 respondents in the 31-44 age group and 87 respondents in the $45+$ age group. In the multivariate analysis of variance, using the age of teachers as the independent variable and the scales of the LBDQ-XII as independent varible, the hypothesis was not rejected at the .05 level of significance.

The respondents' age groupings showed that 88 of the teachers returning the questionnaire were in the maintenance age of 45 years or older with 95 of the respondents in the stabilization age group of 31-44 years. Only 19 respondents were in the trial stage of 22 to 30 years of age. This indicated that the respondents to the study were a group of mature teachers.

Hypothesis 5: Teachers' perceptions of the leadership behavior of their principals, based on the LBDQ-XII subscales, do not differ according to the levels of assignment of the teachers. (p. 8)

Responses to the questionnaire showed that the teachers at Grades $\mathrm{KG}-6$ and Grades 7-9 had their highest mean scores at the Initiation of structure subscale and their lowest mean score at the Integration subscale. The teachers at Grades 10-12 had their highest mean scores at 
the Role Assumption subscale and their lowest subscale score at the Predictive Accuracy subscale.

In the multivariate analysis of variance, using the level of teaching assignment as the independent variable and the scales of the LBDQ-XII as dependent variables, the hypothesis was not rejected at the .05 level of significance.

Hypothesis 6: Teachers and principals' perceptions of the leadership behavior of the principals, based on the LBDQ-XII subscales, do not differ. (n. 8)

In the multivariate analysis of variance, using the perceptions of teachers and principals of the leadership behavior of principals as the independent variable and the scales of the LBDQ-XII as dependent variables, the hypothsis was rejected at the .05 level of significance. In the subsequent univariate analyses of variance, the null hypothesis was rejected at the .05 level of significance for the following variables: Tolerance of Freedom, Consideration, Predictive Accuracy, and Integration.

The mean score of the teachers' responses to the Tolerance of Freedom subscale was 37.0 and the principals had a mean score of 40.7 . The mean score of the teachers' responses on the Consideration subscale was 35.5 , and the principals' responses had a mean score of 40.6 . On the Predictive Accuracy subscale, the teachers' responses had a mean score of 17.2 while the principals' mean score was 19.8. The Integration subscale had means score of 17.2 for 
the teachers' responses and 20.2 for the principals' responses. The teachers' responses had the lowest mean score at the Integration subscale while the principals' lowest mean score was at the Reconciliation subscale.

\section{CONCLUSIONS}

A body of research suggested that effective leadership behavior by principals can enhance teachers' acceptance, respect, and understanding in establishing goals for successful school operations. The process of this leadership depended upon the development of a positive relationship between the principals and teachers.

The findings of this study revealed that there were significant differences between perceptions of the teachers and principals regarding principals' leadership behavior as measured on four of the twelve subscales of the LBDQ-XII. The subscales of Tolerance of Freedom, Consideration, Predictive Accuracy, and Integration showed signficant differences at the .05 level. The eight subscales of Representation, Demand Reconciliation, Tolerance of Uncertainty, Persuasiveness, Initiation of Structure, Role Assumption, Production Emphasis, and Superior Orientation did not show significant differences at the .05 level. In a study of 203 principals, Sweeney (1980) identified major barriers to principals' acceptance of teacher participation in decision making. His study pointed to "a general lack 
of confidence and trust in teachers, manifested by principals' perceptions of teachers as a group seeking power, misusing freedom, needing close supervision, and unwilling to accept responsibility" (p. 565). The significant differences in Tolerance of Freedom, Consideration, Predictive Accuracy and Integration reported here agreed with the conciusions reported in Sweeney's study.

Examination of the twelve subscale means of The teachers and principals' responses in Table XIII revealed that principals consistently rated themselves higher than did teachers. Previous studies by Mahdi (1984), Sukhabanij (1980), and Daniels (1981) also concluded that teachers and principals differed on their perceptions of the leadership behaviors of the principals with principals rating themselves higher than the teachers.

Data supported five of the six hypotheses. There are no significant differences in the way teachers perceive their principals' leadership behavior on the twelve subscales of the LBDQ-XII when gender, age, levels of training, years of teaching experience, and level of teaching assignment are considered.

The research data on leadership behavior indicated that both male and female teachers tend to perceive the principal's leadership behavior similarly as measured by the LBDQ-XII. Data in the study reported here found no 
significant differances between femaie and male teachers' perception of their principal's leadership behavior. This supports the findings of Sukhabaniz (1980) and Ali (1984); their studies also found that there were no differences in teachers' perceptions of leadership behavior by their principals when gender was considered. Both male and female respondents scored the principals' leadership behavior lowest in the area of Integration and highest in the Initiation of stricture subscale in this study.

The levels of training of the teachers had no significant impact on the way they perceived the leadership behavior of their principals. Similarily, the academic degrees held by teachers did not affect their responses, and there were no significant differences in their scores. They rated principa?s' leadership behavior highest in Initiation of structure and Integration lowest in their scoring. The number of years that teachers taught and the age of teachers did not result in a significant difference in their perception of their principals' leadership behavior. This study's findings were similar to the findings in the 1982 study done by Dhanasobhon in Thailand; he found that differences in teachers' sex, educational background, and the number of years in teaching had no significant effect on the perceptions of leadership styles of their principals. This oregon study showed that teachers at the elementary, intermediate, and secondary level do not differ 
significantly in their perceptions of the leadership behavior of their principals. All levels had the highest mean scores on the twelve subscales of the LBDQ-XII in Role Assumption; however, the secondary teachers had the lowest mean score on Predictive Accuracy subscale while the elementary and the intermediate teachers had Integration with the lowest mean score. This study agrees with Rlein's study (1980) which investigated teachers' perceptions of principals' leadership behavior and the degree of willingness to comply with principals' administrative decisions. Klein found that teachers at different school levels did not differ in their perceptions of leadership behavior.

This study suggested that teachers differ little in their perceptions of the leadership behavior of their principals, when gender, level of training, years of exerience, age, or level of assignment is considered. However, the differences between the teachers' and principals' responses were significant with regard to the way in which they perceive the principals' leadership behavior.

\section{RECOMMENDATIONS}

As described in the delimitations of the study, the data was gathered in one suburban school district with 35 schools. This district was predominately white in 
population; the teachers and principals were in the middle and upper-middle income level. Additional research with a larger base of respondents, including urban, suburban, and rural schools, would broaden the sample to provide further information of teachers and principals' perceptions of leadership behavior. It would also be advantageous to research leadership behaviors in a school district that represented a cross-section of races, as this study was in a predominately white population. A larger study would provide a basis for generalization that was difficult in this study as it was conducted in only one school district.

The data indicated that there were four areas in which the principals and teachers significantly differed on their agreement of leadership behavior. A larger study could support that these four areas may need specific attention of principals and school districts by emphasizing training in the areas which include:

1. Tolerance of Freedom which allows followers scope for initiative, decision, and action;

2. Consideration where the leader regards the comfort, well-being, status, and contributions of followers;

3. Predictive Accuracy where the leader exhibits foresight and ability to predict outcomes accurately; and

4. Integration where the leader maintains a closely 
knit organization and resolves intermember conflicts.

The disagreement on the subscale of Tolerance of Freedom between the teachers and principals appeared to indicate that the ability to exercise some initiative and become involved in decisions and actions could be the subject for additional research. Does this discrepancy exist in other schools, or is it unique to the population of this study? Isolating the items on the subscale, analyzing them, and doing another in-depth survey to determine the principals and teachers' disagreements might be beneficial. The same treatment is recommended to explore why the teachers and principals differed significantly on the subscale of Consideration which asked how the leader regarded the comfort, well-being, status and contributions of followers. A future study might examine more intensively the reasons why teachers scored the Consideration subscale lower than the principals.

Since $55 \%$ of the elementary teachers responded to the questionnaire compared to the $66 \%$ of intermediate and high school teachers, it may be advantageous to study why more secondary teachers than elementary school teachers elected to participate in a voluntary study of their principals' leadership behavior. It should be noted that 162 of the 202 respondents had worked for their present principal, whose leadership behavior they were scoring, three years or less. 
This also could be the Focus for additional research. Do beginning teachers, who do not have tenure, differ in their perceptions of their principals' leadership behavior from the perceptions of teachers with tenure? Do teachers who have worked for principals less than three years score their principals' leadership behavior higher or lower than those teachers who have worked for their principal more than three years and have more experience dealing with the strengths and weaknesses of their principals?

Since the school district in which the study was conducted employs more females than males, the random selection of teachers to participate resulted in the data being furnished predominately by females. More research on how males perceive the leadership behavior of their principals might be appropriate.

The subscales of Predictive Accuracy and Integration appeared to indicate that additional information may be needed on the part of the teachers to fully understand the leadership roles of principals as it pertains to administration, curriculum, and school operations in order to comprehend the expertise involved in foresight, ability to predict outcomes, maintain a closely knit organization and resolve intermember conflicts. Additional studies using different instruments to assess these differences might be necessary to offer further information in these areas. 
Finally, disagreement between principals and teachers regarding principals' leadership behavior in these four subscales suggested that teachers may not be aware of the many demands that are being made upon principals. More is required of leadership in this age of increased competition for funds, changing government regulations, new technology, and changing attitudes of teachers. The principals of today are confronted with a variety of economic, social, cultural, scientific, and political issues.

It also appeared that principals may need to re-evaluate some of their leadership behaviors. Teachers, through their organizations, want their rights and resent autocratic leadership. The results of this study could prove beneficial for staff development. Awareness programs and teacher-principal exchange programs could be considered to provide a better understanding of the principals' roles and responsibilites by their teachers. In this way, the study's results of the principals' leadership behavior might prove beneficial to the suburban school district by helping to achieve the goals set by the principals and teachers. 


\section{BIBLIOGRAPHY}

Ali, S. H. (1984). Leadership behavior of secondary school principals as perceived by teachers and principals in the state of Kuwait. Dissertation Abstracts International, $45,25 \mathrm{~A}$.

Allred, C. D. (1980). The relationship between teacher morale and the principal's administrative leadership style. Dissertation Abstracts International, 41. 421A.

Anderson, C. S. (1982). The search for school climate: A review oi the research. Review of Evaluative Research, 1, 368-420.

Babbie, E. R. (1973). Survey research method. Belmont, California: Wadsworth Publishing.

Baldridge, V. J. (1971). Power and conflict in the university. New York: John Wiley and Sons, Inc.

Barnard, C. (1938). The functions of the executive. Cambridge, Massachusetts: Harvard University Press.

Bass, B. (1960). Leadership, psychology, and organizational behavior. New York: Harper \& Brothers.

Bass, B. (1981). Stodgill's handbook of leadership: revised and expanded edition. New York: Macmillan Publishing Company.

Bennis, W. (1966). Changing organizations. New York: MCGraw Hill.

Bennis, พ. (1984). Transformation power and leadership. In T. J. Sergiovanni \& J. E. Corball (Eds.), Leadership and Organizational Culture. Champaign: University of Illinois Press.

Bennis, W. and B. Nanus. (1985). Leaders, the strategies for taking charge. New York: Harper \& Row.

Bidwell, C. (1965, March). The school as a formal organization. Handbook of Organizations, New York: Rand McNally. 
Blank, R. R. (1986, April). Principal leadership in urban high schools: Analysis of variation in leadership characteristics. Paper presented at annual meeting the American Education Research Association. San Francisco, CA.

Blase, J., Dedrick, C., \& Strathe M. (1986, June). Leadership behavior of school principals in relation to teacher satisfaction and performance. Journal of Humanistic Education and Development. $\underline{24}(4), 159-71$.

Blumberg, A. \& Greenfield, W. (1980). The Effective Principal: Perspertives on School Leadership. Boston: Allyn and Bacon, Inc.

Bogardus, E. S. (1934). Leaders and leadership. New York: Appleton, Century, Crofts, Inc.

Borquist, L. C. (1986). Job satisfaction of administators Public Surburan School District. Dissertation Abstracts International.

Brandt, R. (1987, September). On leadership and student achievement. Educational Leadership, 45 (1), 9-11.

Brown, A. F. (1967, Winter). Reactions to leadership. Educational Administration Quarterly, 3 , 62-73.

Brown, W. T. (1981, January). The makings of a middle school: 21 key ingredients. Principal. $6,(3)$ 18-19.

Burns, J. M. (1978). Leadership. New York: Harper and Row.

Burns, J. M. (1980, July). Military Review. $60,(7), 4-9$.

Buros, O. R. (1978). The eighth mental measurement yearbook, Buros institute of mental measurements. New Jersey: Gryphon Press.

Campiel1, D. P. (1984). Forward. In W.E. Rosenbach \& R. L. Taylor (Eds.), Contemporary Issues in Leadership. Boulder: Westview Press. 
Campbel1, J. P. (1977). Summary comments. In J. G. Hunt \& L. L. Larson (Eds.), Leadership: Cutting Edge. Carbondale, I1l.: SIU Press.

Campbel1, R. F. (1980, Winter). The professorship educational administration--A personal view. Educational Administration Quarterly, 17. (1).

CattelI, K. B. (1951). New concepts for measuring leadership in terms of group syntality. Human Relations, 4 , 161-184.

Chapple, E. \& Gordon, D. (1946, Winter). A method for evaluating supervisory personnel.

Harvard Business Review, 24, 201-203.

Cohen, M. (1983). Instructional management and school conditions in effective schools. In $A$. Odden \& L. D. Webb (Eds.), School Finance and School Improvement: Linkages in the $1980^{\prime} \mathrm{s}$. Cambridge: Ballinger.

Cook, E. (1965). Leadership behavior of elementary school principals and the organizational climate of the schools which they administer. Dissertation Abstracts International, 27, 345A.

Conrath, J. (1987, October). The amazing role of leadership: Do you have a choice? NASSP. 126-132.

Crogham, J.H. (1969). A study of the relationships between perceived behavior of elementary principals and informal group dimensions and composition in elementary schools. Dissertation Abstracts International, 30, 3220A.

Daniels, S. C. (1981). Principals' leadership in inner city schools: A comparative study of leaderhip behavior, job satisfaction, and student achievement. Dissertation Abstracts International, $\underline{42}, 3822 \mathrm{~A}$.

Daresh, J. C.\& Liu, C.J. (1985). High school principals' perceptions of their instructional leadership behavior. Paper presented at the Annual Meeting of the American Educational Research Association, 1985 .

Davis T. R. \& Luthans, F. (1979). Leadership re-examined: A behavioral approach. Academic Management Review. 4. 237-348. 
De Bevoise, W. (1979). Synthesis of research on the principal as instructional leader.

Educational Leadership, 41 (5), 15-20.

Devault, J. A. (1981). A study of the relationship between principal leadership styles and teachers' morale in the secondary schools of Virginia. Dissertation Abstracts International, 43, 3165.

DeVries, M. F. (1977). Crisis, leadership, and the parnoid potential: An organizational perspective. Bulletin: Menninger Clinic, 4l, 349-365.

Dimock, M. (1958). A philosophy of administration. New York: Harper.

Doll, R. C. (1973). Leadership to improve schools. Worthington, Ohio: Charles $A$. Jones Publishing Company.

Drucker, P. F. (1985). Innovation and entrepreneurship: practice and principle. New York: Harper \& Row.

Dufour, R. \& Eaker, R. (1987, September). The principal as a leader: Two major responsibilities. National Association of Secondary school Principals, 71 , 80-89.

Duke, D. L. (1985, Fall). Evaluating the performance of Principals. Education Administration Quarterly.

Edmonds, R. (1979). Effective school for the urban poor. Educational Leadership, 15-37.

Feigl, H. (1951). Principles and problems of theory construction in psychology. Current Trends in Psychological Theory (p. 183). Pittsburgh: University of Pittsburgh Press.

Fiedler, F. E. (1967). A theory of leadership effectiveness. New York: McGraw-Hill.

Fiedler, F. E. (1976). Improving leadership effectiveress. New York: John Wiley \& Sons.

Feitler, F. C. (1972, April). A study of principal leader behavior and contrasting organizational environments. Paper Presented at Annual Meeting American Educational Research Association, 1-15 (Eric Document 065-900). 
Fowler, F. J. Jr. (1985). Survey research methods Beverly Hills: Sage Publications.

Freeston, K. R. (1987, May). Leader substitutes in educational organizations. Educational Administration quarterly. $23: 3$ 45-59.

Geneen, H, \& Moscow, A. (1984). Managing. Garden City, New York: Doubleday.

Getzels, J. W. \& Guba ,E. G. (1957, Winter). Social behavior and the administrative process. School Review, 65, 423-441.

Glasman, N. S. (1984). Student achievement and the principal. Educational Evaluation and Policy Analysis, 6 (3), 283-297.

George, P. S. (1983). Confessions of a consultant. Middle School Journal, 15(4), 6 .

Gibb, C. A. (1969). Leadership. In G. Lindzey \& E. Aronson (Eds.) Handbook of Social Psychology (2nd ed.). New York: Addison-Wesley.

Goldman, J. (1983, March). The supervisor's belief about people and the supervisory plan: McGregor's Theory X and Theory in the schools. The clearing House, $\underline{56}$ (7), 306-309.

Gould, S. \& Hawkins, B. L. (1978). Organizational career stage as moderator of the satisfaction performance relationship. Academy of Management Journal, 21 . 434-450.

Griffiths, D. E. (1956). Human relations in school administration. New York: Appleton-Century-Crofts, Inc.

Gross, N. \& Herriott, R. E. (1956). Staff leadership in public schools. New York: John Wiley \& Sons, Inc.

Hallinger, P., Mitman, A. \& \& Murphy, J. (1983, Fall). Problems with research on educational leadership: Issues to be addressed. Educational Evaluation and Policy Analysis, $5,(3)$, pp.297-305.

Halpin, A. W. (1959). The leadership behavior of school superintendents. Chicago: Midwest Administration Center, University of Chicago. 
Halpin, A. W. (1955, November). The leader behavior and leadership ideology of education administrators and aircraft commanders. Harvard Educational Review. 25,28 .

Hefty, J. C. (1971). The relationships between the value orientations, leader behavior and effectiveness of secondary school principals in selected middle sized school systems. Dissertation Abstracts International, 32, 4286A.

Hemphill, J. R. (1949). Situational factors in leadership. Columbus: Ohio State University Press.

Henry, W. E. (1949, January). The business executive: The psychodynamics of a social role. American Journal of Sociology, 54, 286-291.

Hersey, P. \& Blanchard, R. H. Life cycle of leadership. Training and Development Journal, $\underline{23}, 26-34$.

Hodgkinson, C. (1983). The philosophy of leadership. New York: St. Martin's Press.

Hollander, E. P. (1978, November). What is the crisis of leadership. Humanitas. (14) 3, 285-296.

Iacocca, L. \& Novak, W. (1984). Iacocca. New York: Bantam Books.

Ranter, R. M. (1979, July-August). Power failure in management circuits. Harvard Business Review. 65-75.

Kanter, R. M. (1983). The change masters: Innovation and entrepreneurship in the American corporation. New York: Simon and Schuster.

Rerlinger, F.N. (1964). Foundations of behavioral research. New York: Holt, Rinehart \& Winston.

Kerlinger, F. N. (1973). Foundations of behavioral research. New York: Hold, Rinehart \& Winston.

Khoury, N. E. (1981). A comparative analysis of leader behavior of university department chairman, secondary school principals and elementary school principals. Dissertation Abstracts International, 42, 4673A. 
Klein, J. (1980). The relationship between teachers' perceptions of principals' leadership behavior and teachers' degree of complying with principals' administrative decisions. Dissertation Abstracts International, 41, 131.3A.

Knickerbocker, I. (1948). Leadership: A conception and some implications. The Journal of Social Issues, 4. 39 .

Rnopp, R. The leadership styles of principals and teachers job satisfaction with supervision and participation in decision making. Paper presented at meeting of Canadian Assoc. For Study of Educational Administration. Halifax, Nova Scotia. (Eric Doc. Ref. Serv. No. ED 218754).

Kochan, T.A., Schmidt, S. M., \& DeCotiis, T.A. (1975). Superior-subordinate relations: leadership and headship. Human Relations, 28, 279-294.

Krueger, D. A. (1984). Secondary school climate relative to building leadership behavior (effectiveness, administration, learning environment). Dissertation Abstracts International, 45, 3498A.

Kunz, D. (1973). Leader behavior of principals and the professional zone of acceptance of teachers. Dissertation Abstracts International, 34, 3770A.

Lambert, D. B. (1971). A study of relationships between teacher morale and the school principal's leader behavior. Dissertation Abstracts International. 29, 2484A.

Landers, T. J. \& Myers, J. G. (1977). Essentials of management. Philadelphia: W. B. Sanders.

Lassey, W. R. (1971) . Leadership and social change. Iowa City, Iowa: University Associates.

Lindzey, G. (1954) . Handbook of social psychology. Reading, Mass.: Addison, Wesley.

Lipham, J. M. \& Hoeh, Jr. J. (1974). The principalship: foundations and functions. New York: Harper \& Row.

Lipham, J. M., Rankin, R.E., \& Hoeh, Jr. J. (1985) . The principalship: concepts, competencies, and cases. New York: Longman. 
Long, J. W. (1971, February). An analysis of relationships between perceived leader behavior of elementary s thool principals and organizational processes of schools. Paper Presented. 36 pp. (Eric Documents, 047-370).

Mahdi, A. A. (1984). Elementary school principal's leadership behavior as perceived by themselves and their teachers in Baghdad City, Irag. Dissertation Abstracts International, 14, 3562.

Mann, R. D. (1954). A review of the relationship between personality and performance in small groups. Psychological Bulletin, 56, 241-270.

McGee, J. \& Eaker, R. (1978, August). A research study: The practive of supervision in junior high and middle schools. Middle school Journal, 10-1l.

McGhee, P. (1971). An investigation of the relationships between principals' decision-making attitudes, leader behavior and teacher grievances in public schools. Dissertation Abstracts International, 32, 4294A.

MCRague, T. R. (1970, Autumn), LPC--A new perspecitve on leadership. Educational Administration Quarterly. 6. $1-4$.

McNeil, E. (1961, Novmber). The principal--An educational Dinosaur? The National Elementary Principal, 4l, 59-64.

Misumi, J. (1985). The behavioral science of leadership. Ann Arbor: $U$ of Michigan Press.

Morris, V.C., Crowson, R., Porter-Gehrie, C., \& Hurwitz, Jr., E. (1984). Principals in action. Columbus, Ohio: Charles E. Merrill Publishing,

Murphy, J., Hallinger, P., \& Mitman, A. (1983, Fall). Problems with research on educational leadership: Issues to be Addressed. Educational Evaluation Policy Analysis. 5(3) pp. 297-305.

Naisbitt, J. \& Aburdene, P. (1985.) Ten new directions transforming our lives. New York: Warner Books .

National Association of Secondary School Principals. (1984). Assessment Center Final Report. Reston, VA: The Association. 
Perry, M. (1980). The relationship between teacher morale and perceived leader behavior in the junior high schools of a selected metropolitan district in Oklahoma. Dissertation Abstracts International, 41, 1579A.

Persell, C. H., Cookson, P W. \& Lyons, H. (1983, October). Effective principals: What do we know from various educational literature. Paper for the National Conference for Principals.

Peters, T. \& Austin, N. (1985). A passic. for excellence: the leadership difference. New York: Random House.

Peters, T. J. \& Watermam, R. H. (1982). In search of excellence: lessons from America's best run companies. New York: Harper Row.

Pfeffer, $\{1977$, January). Academy of management review, $\underline{2}(1), 101-112$.

Redfern, G. B. (1966). Improving principal faculty relationships. Englewood Cliffs, New Jersey: Prentice Hall Inc.

Riegle, J. D. (1971). A study of middle school programs to determine the current level of implementation of eighteen basic middle school principles. Dissertation Abstracts International, 32, $2977 \mathrm{~A}$.

Robinson, G. E., \& Block, A. H. (1982, November). The principal and achievement: A summary of 22 studies. Principal, 62, (2), 53-57.

Rogers, E. M. (1983) Diffusion of innovations. New York: The Free Press.

Sanford, F. H. (1951). Leadership identification and acceptance. Groups, Leadership, and Men: Research in Human Relations. Pittsburgh: Carneige Press.

Sergiovanni, T.J. (1982). Ten principles of quality leadership. Educational Leadership, 39, 334-336.

Schriesheim, C.A., Tolliver, J.M. \& Behling, O. C. (1978, Summer). Leadership theory: Some implications for managers. MSU Business Topics, 22(3), 34-40. 
Scott-Miller, S.(1984). An investigation of the relationship between biographical characteristics and job satisfaction among middle school teachers in four suburban school districts. Dissertation Abstracts International. $46,41 \mathrm{~A}$.

Sims, H. (1977). The leader as a manager of reinforcement contingencies. In J. G. Hunt \& L. L. Larsen (Eds.), Leadership: the cutting edge (p. 239). Carbondale: South Illinois University Press.

Solomon, G. (1983, March). Teacher rating principals: A sobering experience. Principal, $\underline{62}(4), 14-17$.

Spreicher, D. (1971). Evaluation of administration and supervisory personnel. Personnel News for School systems, 40, 9-10.

Stanavage, J. (1967, Noverember). Educational leader: An authentic role. The National Association of Secondary School Principals Bulletin, 51, 3-17.

Stogdill, R. M. (1974). Handbook of leadership: A survey of theory and reasearch New York: The Free Press.

Stogdill, R. M. (1963). Manual for the leader behavior description questionnaire-form XII. Columbus, Ohio: Bureau of Business Research, The Ohio state University.

stogdill, R. M. (1948). Personal factors associated with leadership: A survey of the literature. Journal of Psychology, 25, 35-71.

Stogdill, R. W. (1969, summer) . Validity of leader behavior descriptions. Personnel Psychology, 22, 153-158.

Sweeney, J. (1980, April). Principals vs: teachers. Phi Delta Rappan, 565-566.

Sukhabanij, S. (1980). An investigation of principal's leadership behavior as perceived by secondary school principals and teachers in Nakorn, Thailand. Dissertation Abstracts International, 41, 2873.

Tannenbaum, R., Weschler, I. \& Massarik, F. (1961). Leadership and Organization: A Behavorial Science Approach. New York: McGraw Hill Book Co. 
Tead, 0. (1935). The art of leadership. New York: McGraw-Hill Book Company.

Thurstone, L. (1944). A factorial study of perception. Chicago: University of Chicago Press.

Tichy, N. M \& DeVanna, M. A. (1986). The transformational leader. New York: John Wiley \& Sons.

Vroom, V. H. (1977). Can leaders learn to read. In J. R. Hackman, E. E. Lawler, III, \& L. W. Porter (Eds.), Perspectives on Behavior in Organizations. New York: McGraw-Hill, 1977.

Wagstaff, L. G. (1973, November). Unionized principal-You may be next. The National Association of Secondary School Principals Bulletin, 57, 43-44.

Watson, B. (1965). A study of the relationships among selected aspects of administrative behavior and teacher group cohesiveness in the elementary school. Dissertation Abstracts International, 26, 1463.

White, R. \& Lipitt, R. (1968). Leadership behavior and member reaction in three social climates. In $D$. Cartwright \& A. Zander (Eds.), Group dynamics (3rd ed.). New York: Harper \& Row.

Willower, D. J. (1960). Leadership styles and leaders' Perceptions of subordinates. Journal of Educational Psychology, 58-64.

Yukel, G. (1982). Managerial leadership and the effective principal. In The Effective Principal: A

Research Summary. Washington, D. C.: National Association of Secondary School Principals, 1982.

Zaleznik, A. (1974, May). Charismatic and consensus leaders: A psychological comparison. Bulletin of the Menninger Clinic, $38(2), 222-238$.

Zierden, W. E. (1984). Leading through the follower's point of view. In W. E. Rosenbach \& R. L Taylor (Eds.), Contemporary Issues in Leadership. Boulder: Westview Press. 
APPENDIX A

LEADER BEHAVIOR QUESTIONNAIRE-FORM XII 


\title{
LEADER BEHAVIOR DESCRIPTION QUESTIONNAIP.E-FOIM XII
}

\author{
Originated by staft members of \\ The Ohlo State beadershlp Studies \\ and revised by the \\ Bupous of Business Resesich
}

\begin{abstract}
Purpose of the Questionnaire
On the following pages is a list of items that may be used to describe the behavior of your supervisor. Each item describes a specific kind of behavior. but does not ask you 10 judge whether the behavior is desirable or undesirable. Although some items may appear similar. they express differences that are imporant in the desenption of leadership. Each item should be considered as a separate deseription. This is not a lest of ability or consistenes in making answers. Its only purpose is 10 make it possible for you to describe. as accuralely as you can. the behavior of yout supepvisor.
\end{abstract}

Note: The term. "group." as employed in the following items. refers to a depanment division. or other unit of organization that is supervised by the person being described.

The lerm "membrrs." refers to all the people in the unit of organizalion that is supervised by the person being described. 
DRECTIONS:

a. READ each item carefully.

b. THINK aboul how frcquently the leader engages in the behavior described by the item.

c. DECIDE whether he/she (A) always, (B) ofien, (C) occasionally, (D) seldom or (E) nevel acis as deseribed by the item.

d. DRAW A CIRCLE around one of the five ietters (A B C D E) following the item lo show the answer you have selected.

$$
\begin{aligned}
& A=\text { Always } \\
& B=\text { Often } \\
& C=\text { Oceasionally } \\
& D=\text { Seldom } \\
& E=\text { Never }
\end{aligned}
$$

e. MARK your answers as shown in the examples below.

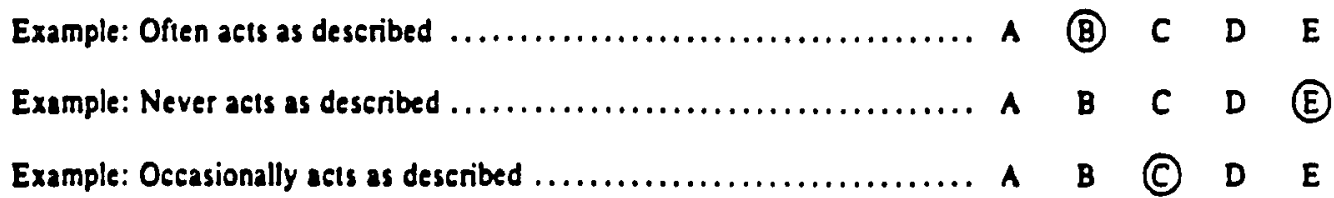

1. Acts as the spokesperson of the group ........................A A B C D E

2. Waits patiently for the results of a decision ...................A B C $B$ D

3. Makes pep talks to stimulate the group $\ldots \ldots \ldots \ldots \ldots \ldots \ldots \ldots \ldots A$ A $B$ C $\quad D \quad E$

4. Lets group members know what is expected of them ..............A A $B \quad C \quad D \quad E$

3. Allows the members complete freedom in their work..............A A $B$ C $E$

6. ls hesitant about luking initiative in the group ................. A B C D E

7. Is friendly and approachable $\ldots \ldots \ldots \ldots \ldots \ldots \ldots \ldots \ldots \ldots \ldots \ldots$ A $B$ C $C$ D

8. Encounges overtime work ...............................A B C D E

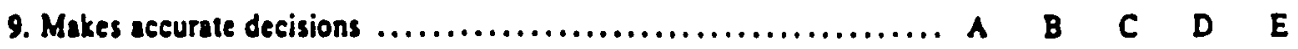

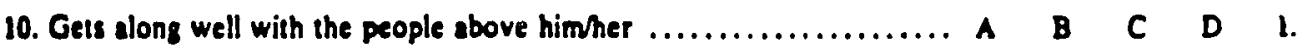

11. Publieizes the aetivities of the group ........................A B C D E

12. Becomes anxious when he/she cinnot find out what is coming next... A A $A$ C $C$ D $E$ 


$$
\begin{aligned}
& A=\text { Always } \\
& B=\text { Ofien } \\
& C=\text { Occasionally } \\
& D=\text { Seldom } \\
& E=\text { Never }
\end{aligned}
$$

13. Hisher arguments are convincing $\ldots \ldots \ldots \ldots \ldots \ldots \ldots \ldots \ldots \ldots \ldots$ A B $C$ C D E

14. Encourages the use of uniform procedures $\ldots \ldots \ldots \ldots \ldots \ldots \ldots \ldots \ldots$ A B C D $E$

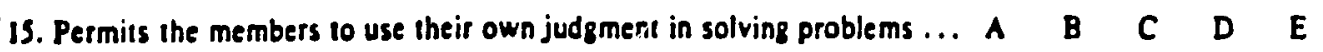

16. Fails to take necessary action..........................., A B C D E

17. Does little things 10 make it pleasant to be a member of the group.... A $A$ B C $\quad$ E

18. Stresses being ahead of competing groups $\ldots \ldots \ldots \ldots \ldots \ldots \ldots \ldots \ldots$ A B $C$ D $E$

19. Keeps the group working together as a team $\ldots \ldots \ldots \ldots \ldots \ldots \ldots \ldots$ A $B$ B $C$ D $E$

20. Keeps the group in good standing with higher authorily ...........A A B $\quad$ C $\quad D \quad E$

21. Speaks as the representative oi the group $\ldots \ldots \ldots \ldots \ldots \ldots \ldots \ldots \ldots$ A B $C$ D $E$

22. Accepts defeat in stride $\ldots \ldots \ldots \ldots \ldots \ldots \ldots \ldots \ldots \ldots \ldots \ldots \ldots \ldots \ldots \ldots \ldots \ldots \ldots$

23. Argues persuasively for hisher point of view ................A B C D E

24. Tries out his/her ideas in the group $\ldots \ldots \ldots \ldots \ldots \ldots \ldots \ldots \ldots \ldots, A$ B $C$ D $E$

23. Encourages initiative in the group members $\ldots \ldots \ldots \ldots \ldots \ldots \ldots \ldots$ A $B$ B $C$ D $E$

26. Lets other persons take away hisher leadership in the group $\ldots \ldots \ldots$ A $B$ B $C$ D $E$

27. Puts suggestions made by the group into operation ..............A B C D E

28. Needles members for greater effion $\ldots \ldots \ldots \ldots \ldots \ldots \ldots \ldots \ldots \ldots \ldots, A$ B $C$ D $E$

29. Seems able to prediet what is coming next $\ldots \ldots \ldots \ldots \ldots \ldots \ldots \ldots \ldots$ A $B$ B $C$ D $E$

30. Is working hard for a promotion $\ldots \ldots \ldots \ldots \ldots \ldots \ldots \ldots \ldots \ldots \ldots \ldots$, B $C$ D $E$

31. Speaks for the group when visitors are present $\ldots \ldots \ldots \ldots \ldots \ldots \ldots$ A B C D E

32. Accepts delays without becoming upset .....................A B B C D E

33. Is a very persuasive ulker $\ldots \ldots \ldots \ldots \ldots \ldots \ldots \ldots \ldots \ldots \ldots \ldots \ldots$ A B $\mathrm{C}$ D $E$

34. Makes hisher attitudes clear to the group $\ldots \ldots \ldots \ldots \ldots \ldots \ldots \ldots \ldots$ A B $C$ D $E$

35. Lets the members do their work the way they think best $\ldots \ldots \ldots \ldots . A$ B $C$ D $E$

36. Lets some members take advantage of himher $\ldots \ldots \ldots \ldots \ldots \ldots \ldots \ldots A$ A $C$ D $E$ 


$$
\begin{aligned}
& A=\text { Always } \\
& B=\text { Ofien } \\
& C=\text { Oecasionally } \\
& D=\text { Seldom } \\
& E=\text { Never }
\end{aligned}
$$

37. Treats all group members as hishet equals

A B C D E

38. Keeps the work moving a a rapid pace $\ldots \ldots \ldots \ldots \ldots \ldots \ldots \ldots \ldots$, A $B$ B $C$ D $E$

39. Settles conflicts when they occur in the group ..................A B $C$ D $E$

40. His/her superiors act favorably on most of his/her suggestions........ A B C D E

41. Represents the group at outside meetings $\ldots \ldots \ldots \ldots \ldots \ldots \ldots \ldots \ldots$ A B C D E

42. Becomes anxious when waiting for new developments...........A B $C$ D $E$

43. Is very skillful in an argument $\ldots \ldots \ldots \ldots \ldots \ldots \ldots \ldots \ldots \ldots \ldots, A$ B $C$ D $E$

4. Decides whal shall be done and how it shall be done ............A A B C $\mathrm{B}$ E

45. Assigns a lask. then lets the members handle it...............A B $C$ D $E$

46. Is the leader of the group in name only $\ldots \ldots \ldots \ldots \ldots \ldots \ldots \ldots \ldots$ A B $C$ D $E$

47. Gives adrance nolice of changes $\ldots \ldots \ldots \ldots \ldots \ldots \ldots \ldots \ldots \ldots \ldots$ A B $C$ C D E

48. Pushes for increased production $\ldots \ldots \ldots \ldots \ldots \ldots \ldots \ldots \ldots \ldots \ldots$ A B C D E

49. Things usually turn oul as he/she predicts ................... A B C D E

50. Enjoys the privileges of hisher position ...................A B C D E

S1. Handles complex problems efficiently ..................... A B C D $E$

S2. Is able to tolerate postponement and uncertainty..............A $A$ B $C$ D $E$

53. Is not a very convineing talker $\ldots \ldots \ldots \ldots \ldots \ldots \ldots \ldots \ldots \ldots \ldots \ldots$ A B C $D$ E

SA. Assigns group members to particular tasks $\ldots \ldots \ldots \ldots \ldots \ldots \ldots \ldots \ldots$ A B C D E

5s. Tums the members loose on a job, and lets them 80 to it $\ldots \ldots \ldots \ldots \ldots A$, B C $C$ D

56. Becks down when he/she ought to stand firm ................A B C D E

57. Keeps to himselt/herself..............................A B C D E

98. Asks the members to work harder.........................A B C D E

59. Is accurate irt predicting the trend of events $\ldots \ldots \ldots \ldots \ldots \ldots \ldots \ldots \ldots$ A B $C$ C $D \quad E$

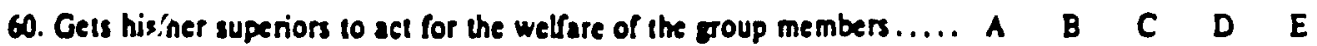




$$
\begin{aligned}
& A=\text { Always } \\
& B=\text { Ofien } \\
& C=\text { Occasionally } \\
& D=\text { Seldom } \\
& E=\text { Never }
\end{aligned}
$$

61. Gets swimped by details $\ldots \ldots \ldots \ldots \ldots \ldots \ldots \ldots \ldots \ldots \ldots \ldots \ldots$ A B $C$ D $E$

62. Can wait just so long, then blows up $\ldots \ldots \ldots \ldots \ldots \ldots \ldots \ldots \ldots \ldots A$ A $C$ C $D$ E

63. Speaks from a strong inner conviction $\ldots \ldots \ldots \ldots \ldots \ldots \ldots \ldots \ldots \ldots$ A B $C$ D $E$

64. Makes sure that hisher pan in the group is understood

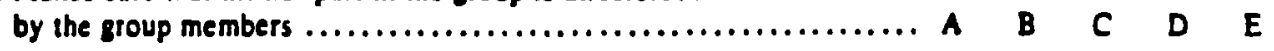

65. Is reluciant 10 allow the members any freedom of action...........A A B C $D$ D

66. Lets some members have authority that he/she should keep.........A $B$ B $C$ D $E$

67. Looks oul for the personal welfare of group members $\ldots \ldots \ldots \ldots \ldots \ldots$ A B $C$ C D E

68. Permits the members to take it easy in their work $\ldots \ldots \ldots \ldots \ldots \ldots$ A B $C$ C D $E$

69. Sees 10 it that the work of the group is coordinaled ..............A B $C$ D $E$

70. His/her word carries weight with superiors $\ldots \ldots \ldots \ldots \ldots \ldots \ldots \ldots$ A B $C$ C D $E$

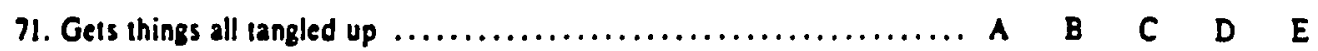

72. Remains calm when uncertain about coming events .............A A $\quad$ B $C$ D $E$

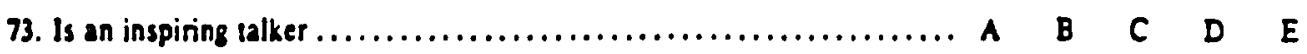

74. Schedules the work to be done $\ldots \ldots \ldots \ldots \ldots \ldots \ldots \ldots \ldots \ldots \ldots \ldots$ A B $C$ C D E

75. Allows the group a high degree of initiative $\ldots \ldots \ldots \ldots \ldots \ldots \ldots \ldots$ A B $C$ D $E$

76. Takes full charge when emergencies arise $\ldots \ldots \ldots \ldots \ldots \ldots \ldots \ldots \ldots$ A B C D E

7. Is willing to make changes $. . \ldots \ldots \ldots \ldots \ldots \ldots \ldots \ldots \ldots \ldots \ldots, \ldots \ldots \ldots$

78. Drives hard when there is a job to be done $\ldots \ldots \ldots \ldots \ldots \ldots \ldots \ldots \ldots$ A $B$. C D E

79. Helps sroup members setlle their ditrerences $\ldots \ldots \ldots \ldots \ldots \ldots \ldots \ldots$ A \& $C$ C D E

80. Gets what he/she asks for from hisher superiors ................A B $C$ C D $E$

81. Can reduce a madhouse to system and order $\ldots \ldots \ldots \ldots \ldots \ldots \ldots \ldots$ A B $C$ C D E

82. Is able to delay action until the proper time oceur ...............A B $C$ D $E$

83. Persuades oliers that hisher ideas are to their advantage $\ldots . \ldots \ldots \ldots, A$ B $C$ C $E$ 


$$
\begin{aligned}
& A=\text { Always } \\
& B=\text { Often } \\
& C=\text { Occasionally } \\
& D=\text { Seldom } \\
& E=\text { Never }
\end{aligned}
$$

84. Maintains definite standards of performance.

$\begin{array}{lllll}A & B & C & D & E\end{array}$

\section{- 85}

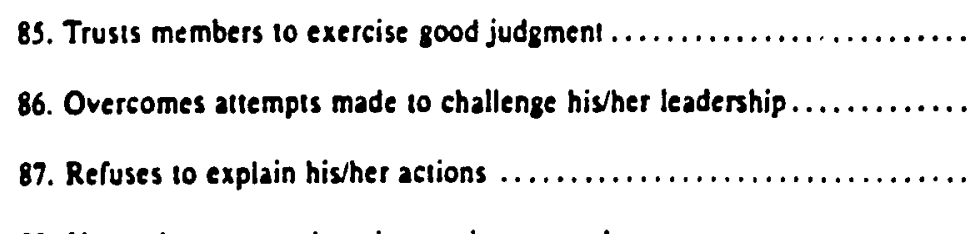

A B C D E

88. Urges the group to beat its previous record A B C D E

89. Anticipates problems and plans for them A B C D E

90. Is working his/her way to the top

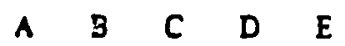

91. Gets confused when 100 many demands are made of him/her. A B C D $E$

92. Worries about the outcome of any new procedure A $B$ C D $E$

93. Can inspire enthusiasm for a project A B C D E

94. Asks that group members follow standard rules and regulations. A B C D E

95. Permils the group to set its own pace... A $B$ C D $E$

96. Is easily recognized as the leader of the group A B C D $\quad$ E

97. Acts withoul consulting the group $\ldots \ldots \ldots \ldots \ldots \ldots \ldots \ldots \ldots \ldots$ A $B$. $C$ D $E$ A B C D $E$

98. Keeps the group working up to capacity $\ldots \ldots \ldots \ldots \ldots \ldots \ldots \ldots$ A B C D E

99. Maintains a closely knit group ............................ A B C D E

100. Maintains cordial relations with superiors ..................... A B $C$ D E 
Business Research Support Services

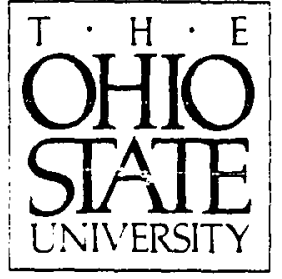

College of Business 1775 College Road

Columbus, OH 43210-1309

Phone 614-292-9300

\section{February 3,1988}

Ms. Darleen Huber-Dilbeck

14655 N.W. Bonneville Loop

Beaverton, OR 97006

Dear Ms. Huber-Dilbeck:

You have our permission to use the LEADER BEHAVIOR DESCRIPTION QUESTIONNAIRE - Form XII for your doctoral thesis.

Please follow the guidelines listed in the attached Statement of Policy.

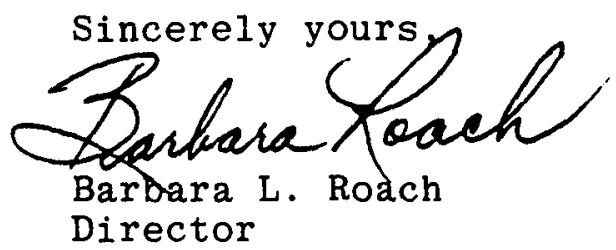

$\underline{B L R}$

ahr 
APPENDIX B

RELIABILITY COEFFICIENTS 


\begin{tabular}{|c|c|c|c|c|c|c|c|c|c|}
\hline Subscaie & $A D *$ & $\mathrm{KP}^{\circ}$ & $A E \div$ & $M \xi$ & CLT & CPn & LPL & $\omega s$ & $s^{\prime}$ \\
\hline 1. Representation & .82 & .85 & .74 & .55 & .59 & .54 & .70 & .66 & .80 \\
\hline 2. Demand Reconciliation & $\cdots$ & $\cdots$ & .73 & .77 & .58 & .59 & .81 & $\ldots$ & .81 \\
\hline $\begin{array}{l}\text { 3. Tolerance of Vncer- } \\
\text { cainty }\end{array}$ & .58 & .66 & .82 & .84 & .85 & .79 & .82 & .80 & .83 \\
\hline 4. Persuasiveneso & .84 & .85 & .84 & .77 & .75 & .69 & .80 & .76 & .82 \\
\hline $\begin{array}{l}\text { 5. Initiation of Struc- } \\
\text { ture }\end{array}$ & .79 & .75 & .78 & .70 & .72 & .77 & .78 & .80 & .72 \\
\hline 6. Tolerance of Freedom & .31 & .79 & .86 & .75 & .86 & .84 & .58 & .73 & .64 \\
\hline i. Role Assumption & .35 & .84 & .84 & .75 & .83 & .57 & .86 & .75 & .65 \\
\hline 3. Considerati=n & .76 & .37 & .84 & .85 & .77 & .78 & .83 & .76 & .85 \\
\hline 9. Production Emphisis & .70 & .79 & .79 & .59 & .79 & .71 & .65 & .74 & .38 \\
\hline 10. Predictive Accuracy & .76 & .82 & .91 & .83 & .62 & .84 & .87 & $\cdots$ & $\cdots$ \\
\hline 11. Integrattcn & .73 & .79 & $\cdots$ & $\cdots$ & $\cdots$ & $\cdots$ & $\cdots$ & $\ldots$ & $\cdots$ \\
\hline 12. Superfor Orfeatation & .64 & .75 & .81 & $\ldots$ & $\ldots$ & .66 & $\ldots$ & .50 & $\ldots$ \\
\hline
\end{tabular}

*Army Diviston

'HIghway Pacrol

†Atrcraft Execur1ves

EMInisters

Community Leaders

ucorporation Presidenis

ilabor Presidents

fCollege Presidents

'Senators 
APPENDIX C

BACRGROUND INFORMATION 
BACRGROUND INFORMATION: Circle or complete the appropriate response.

1. Are you female or male?

1. FEMALE 2. MALE

2. What is your age to your nearest birthday?

3. Which academic training do you have?

1. Bachelor's 2. Bachelor's plus

3. Master's 4. Master's plus

5. Doctoral

4. How many years have you taught?

5. How many years have taught for the present principal?

6. At what level are you employed?

$\begin{array}{llll}\text { 1. Gr. } \mathrm{K}-6 & 2 . \mathrm{Gr} \cdot 7-9 & 3 \cdot \text { Gr. } 10-12\end{array}$ 
BACKGROUND INFORMATION: Circle or complete the appropriate response.

$$
\begin{aligned}
& \text { 1. Are you female or male? } \\
& \text { 1. FEMALE }
\end{aligned}
$$

2. What is your age to your nearest birthday?

3. Which academic training do you have?

1. Bachelor's 2. Bachelor's plus

3. Master's 4. Master's plus

5. Doctoral

4. How many years have you taught?

5. How many years have you been a building principal?

6. At what level are you employed?

1. Gr. K-6 2. Gr. 7-9 3. Gr. 10-12 
APPENDIX D

LETTERS 
April 24, 1987

Dear Colleague:

As a teacher in the school District, you are being invited to participate in a study of leadership behavior of principals. You have been randomly selected to describe the leadership behavior your building principal. Educational research in the $1980^{\prime}$ 's points out the crucial role of principals in determining school success, and this is an opportunity to share your perceptions of leadership qualities.

Your response to the questionnaire will take fifteen to twenty minutes. It comprises the basis of my research for my doctoral dissertation. Being a teacher in the District for eleven years and presently teaching at School, I realize how busy each of you are and appreciate your assistance and time in completing this form. Your responses will be highly valued. Please enjoy a cup of tea, complete the questionnaire and return it in the addressed, stamped envelope that has been provided for your convenience by May 10.

My study has been approved by Portland state, Superintendent , and the Directors of Elementary and Secondary

Schools. I wish to assure you of complete confidentiality as there is no identification number on the questionnaire and the identity of the respondents will be unknown.

If you have any questions, please call me; and if you wish a summary of the study's finding, feel free to request one after August. Thank you for your cooperation and assistance.

Sincerely,

Darleen Huber-Dilbeck

14655 N.W. Bonneville Loop

Beaverton, OR 97006

Home Phone 645-6346 
April 24, 1987

Dear Principal:

As a Principal in the School District, you are being invited to participace in a study of leadership behavior of principals. You have been randomly selected to describe the leadership behavior your building principal. Educational research in the $1980^{\prime} \mathrm{s}$ points out the crucial role of principals in determining school success, and this is an opportunity to share your perceptions of your leadership qualities.

Your response to the questionnaire will take fifteen to twenty minutes. It comprises the basis of my research for my doctoral dissertation. Being a teacher in the nistrict for eleven years and presently teaching at School, I realize how busy each of you are and appreciate your assistance and time in completing this form. Your responses will be highly valued. Please enjoy a cup of tea, complete the questionnaire and return it in the addressed, stamped envelope that has been provided for your convenience by May 10 .

My study has been approved by Portland state, Superintendent , and the Directors of Elementary and Secondary

Schools. I wish to assure you of complete confidentiality as there is no identification number on the questionnaire and the identity of the respondents will be unknown.

If you have any questions, please call me; and if you wish a summary of the study's finding, feel free to request one after August. Thank you for your cooperation and assistance.

Sincerely,

Darleen Huber-Dilbeck

14655 N.W. Bonneville Loop

Beaverton, OR 97006

Home Phone 645-6346 
APPENDIX E

FOLLOW-UP LETTERS 
MAY 18, 1987

DEAR COLLEAGUE (OR PRINCIPAL):

IN LATE APRIL I MAILED YOU A QUESTIONNAIRE ON LEADERSHIP BEHAVIOR OF PRINCIPALS IN THE__ DISTRICT. I KNOW THIS IS AN EXTREMELY BUSY TIME OF YEAR FOR ALL OF YOU, BUT TO DATE I HAVE RECEIVED A LIMITED RESPONSE TO MY QUESTIONNAIRE. SINCE THE INFORMATION IS CRUCIAL FOR MY RESEARCH FOR MY DOCTORAL DISSERTATION, IF YOU HAVE NOT COMPLETED THE QUESTIONNAIRE, I AGAIN AM ASKING YOU TO PLEASE TARE EIFTEEN MINUTES TO COMPLETE THE FORM AND RETURN IT TO ME. IF YOU HAVE ANY QUESTIONS, PLEASE CALL ME. YOUR HELP WILL BE GREATLY APPRECIATED. THANR YOU.

SINCERELY YOURS, DARLEEN HUBER-DILBECK

HOME PHONE 645-6346 
APPENDIX F

ANALYSIS OF VARIANCE 
APPENDIX $F(1)$

ANALYSIS OF VARIANCE OF TEACHERS' RESPONSES REGARDING

THEIR PRINCIPALS' LEADERSHIP BEHAVIOR ON TWELVE

DIMENSIONS : TEACHERS SEUPED

ACCORDING TO GENDER

\begin{tabular}{|c|c|c|c|}
\hline Subscales & $D F$ & $\begin{array}{r}\text { Sum of } \\
\text { squares }\end{array}$ & P \\
\hline $\begin{array}{l}\text { Representation } \\
\text { Between Groups } \\
\text { Within Groups } \\
\text { Total }\end{array}$ & $\begin{array}{r}1 \\
200 \\
201\end{array}$ & $\begin{array}{r}10.727 \\
1218.243 \\
1228.970\end{array}$ & .186 \\
\hline $\begin{array}{l}\text { Reconciliation } \\
\text { Between Groups } \\
\text { Within Groups } \\
\text { Total }\end{array}$ & $\begin{array}{r}1 \\
200 \\
201\end{array}$ & $\begin{array}{r}.818 \\
2701.563 \\
2702.381\end{array}$ & .806 \\
\hline $\begin{array}{l}\text { Tolerance of Uncertainty } \\
\text { Between Groups } \\
\text { Within Groups } \\
\text { Total }\end{array}$ & $\begin{array}{r}1 \\
200 \\
201\end{array}$ & $\begin{array}{r}1.879 \\
9240.576 \\
9263.154\end{array}$ & .485 \\
\hline $\begin{array}{l}\text { Persuasiveness } \\
\text { Between Groups } \\
\text { Within Groups } \\
\text { Total }\end{array}$ & $\begin{array}{r}1 \\
200 \\
201\end{array}$ & $\begin{array}{r}32.873 \\
9015.905 \\
9048.888\end{array}$ & .394 \\
\hline $\begin{array}{l}\text { Initiation of structure } \\
\text { Between Groups } \\
\text { Within Groups } \\
\text { Total }\end{array}$ & $\begin{array}{r}1 \\
200 \\
201\end{array}$ & $\begin{array}{r}53 \cdot 125 \\
4845 \cdot 251 \\
4998 \cdot 376\end{array}$ & .140 \\
\hline $\begin{array}{l}\text { Tolerance of Freedom } \\
\text { Between Groups } \\
\text { Within Groups } \\
\text { Total }\end{array}$ & $\begin{array}{r}1 \\
200 \\
201\end{array}$ & $\begin{array}{r}12.835 \\
11580.849 \\
11593.683\end{array}$ & .638 \\
\hline
\end{tabular}

*Significant at the .05 level. 
APPENDIX F (1) CONTINUED

ANALYSIS OF VARIANCE OF TEACHERS' RESPONSES REGARDING

THEIR PRINCIPALS' LEADERSHIP BEHAVIOR ON

TWELVE DIMENSIONS: TEACHERS GROUPED ACCORDING TO GENDER

\begin{tabular}{|c|c|c|c|}
\hline subscales & DF & $\begin{array}{r}\text { Sum of } \\
\text { Squares }\end{array}$ & $\underline{P}$ \\
\hline $\begin{array}{l}\text { Role Assumption } \\
\text { Between Groups } \\
\text { Within Groups } \\
\text { Total }\end{array}$ & $\begin{array}{r}1 \\
200 \\
201\end{array}$ & $\begin{array}{r}5.339 \\
6373.394 \\
6378.733\end{array}$ & .683 \\
\hline $\begin{array}{l}\text { Consideration } \\
\text { Between Groups } \\
\text { Within Groups } \\
\text { Total }\end{array}$ & $\begin{array}{r}1 \\
200 \\
201\end{array}$ & $\begin{array}{r}1.419 \\
10214.680 \\
10216.010\end{array}$ & .868 \\
\hline $\begin{array}{l}\text { Production Emphasis } \\
\text { Between Groups } \\
\text { Within Groups } \\
\text { Total }\end{array}$ & $\begin{array}{r}1 \\
200 \\
201\end{array}$ & $\begin{array}{r}23.583 \\
8291.565 \\
8315.149\end{array}$ & .452 \\
\hline $\begin{array}{l}\text { Predictive Accuracy } \\
\text { Between Groups } \\
\text { Within Groups } \\
\text { Total }\end{array}$ & $\begin{array}{l}1 \\
200 \\
201\end{array}$ & $\begin{array}{r}1.905 \\
1666.471 \\
1668.377\end{array}$ & .633 \\
\hline $\begin{array}{l}\text { Integration } \\
\text { Between Groups } \\
\text { Within Groups } \\
\text { Total }\end{array}$ & $\begin{array}{r}1 \\
200 \\
201\end{array}$ & $\begin{array}{r}1.716 \\
3766.527 \\
3768.243\end{array}$ & .763 \\
\hline $\begin{array}{l}\text { Superior Orientation } \\
\text { Between Groups } \\
\text { Within Groups } \\
\text { Total }\end{array}$ & $\begin{array}{r}1 \\
200 \\
201\end{array}$ & $\begin{array}{r}20.569 \\
7407.951 \\
7428.521\end{array}$ & .457 \\
\hline
\end{tabular}

*Significant at the .05 level. 
APPENDIX F(2)

ANALYSIS OF VARIANCE OF TEACHERS' RESPONSES REGARDING THEIR PRINCIPALS' LEADERSHIP BEHAVIOR ON TWELVE DIMENSIONS : TEACHERS GROUPED ACCORDING TO LEVELS OF TRAINING

\begin{tabular}{|c|c|c|c|}
\hline Subscales & DF & $\begin{array}{r}\text { Sum of } \\
\text { Squares }\end{array}$ & P \\
\hline $\begin{array}{l}\text { Representation } \\
\text { Between Groups } \\
\text { Within Groups } \\
\text { Total }\end{array}$ & $\begin{array}{r}3 \\
198 \\
201\end{array}$ & $\begin{array}{r}12.505 \\
1216.465 \\
1228.971\end{array}$ & .566 \\
\hline $\begin{array}{l}\text { Reconciliation } \\
\text { Between Groups } \\
\text { Within Groups } \\
\text { Total }\end{array}$ & $\begin{array}{r}3 \\
198 \\
201\end{array}$ & $\begin{array}{r}94.641 \\
2607.742 \\
2702.381\end{array}$ & .071 \\
\hline $\begin{array}{l}\text { Tolerance of Uncertainty } \\
\text { Between Groups } \\
\text { Within Groups } \\
\text { Total }\end{array}$ & $\begin{array}{r}3 \\
198 \\
201\end{array}$ & $\begin{array}{r}209.491 \\
9953.664 \\
9263.153\end{array}$ & .209 \\
\hline $\begin{array}{l}\text { Persuasiveness } \\
\text { Between Groups } \\
\text { Within Groups } \\
\text { Total }\end{array}$ & $\begin{array}{r}3 \\
198 \\
201\end{array}$ & $\begin{array}{r}282.195 \\
8766.582 \\
9048.777\end{array}$ & .098 \\
\hline $\begin{array}{l}\text { Initiation of structure } \\
\text { Between Groups } \\
\text { Within Groups } \\
\text { Total }\end{array}$ & $\begin{array}{r}3 \\
198 \\
201\end{array}$ & $\begin{array}{r}107.352 \\
4791.024 \\
4898.376\end{array}$ & .222 \\
\hline $\begin{array}{l}\text { Tolerance of Freedom } \\
\text { Between Groups } \\
\text { Within Groups } \\
\text { Total }\end{array}$ & $\begin{array}{r}3 \\
198 \\
201\end{array}$ & $\begin{array}{r}138.621 \\
11455.063 \\
11593.683\end{array}$ & .496 \\
\hline
\end{tabular}

*Significant at the .05 level. 
APPENDIX F(2) CONTINUED

ANALYSIS OF VARIANCE OF TEACHERS' RESPONSES REGARDING THEIR PRINCIPALS' LEADERSHIP BEHAVIOR ON TWELVE DIMENSIONS: TEACHERS GROUPED ACCORDING TO LEVELS OF TRAINING

\begin{tabular}{|c|c|c|c|}
\hline \multirow[b]{2}{*}{ Subscales } & \multicolumn{3}{|c|}{ Sum of } \\
\hline & $D E$ & Sgiares & P \\
\hline $\begin{array}{l}\text { Role Assumption } \\
\text { Between Groups } \\
\text { Within Groups } \\
\text { Total }\end{array}$ & $\begin{array}{r}3 \\
198 \\
201\end{array}$ & $\begin{array}{r}54.253 \\
6324.481 \\
6378.733\end{array}$ & .638 \\
\hline $\begin{array}{l}\text { Consideration } \\
\text { Between Groups } \\
\text { Within Groups } \\
\text { Total }\end{array}$ & $\begin{array}{r}3 \\
198 \\
201\end{array}$ & $\begin{array}{r}98.805 \\
10117.294 \\
10216.099\end{array}$ & .587 \\
\hline $\begin{array}{l}\text { Production Emphasis } \\
\text { Between Groups } \\
\text { Within Groups } \\
\text { Total }\end{array}$ & $\begin{array}{r}3 \\
198 \\
201\end{array}$ & $\begin{array}{r}118.409 \\
8196.739 \\
8315.149\end{array}$ & .416 \\
\hline $\begin{array}{l}\text { Predict:ve Accuracy } \\
\text { Between Groups } \\
\text { Within Groups } \\
\text { Total }\end{array}$ & $\begin{array}{r}3 \\
198 \\
201\end{array}$ & $\begin{array}{r}50.787 \\
1617.589 \\
1668.376\end{array}$ & .105 \\
\hline $\begin{array}{l}\text { Integration } \\
\text { Between Groups } \\
\text { Within Groups } \\
\text { Total }\end{array}$ & $\begin{array}{r}3 \\
198 \\
201\end{array}$ & $\begin{array}{r}83.574 \\
3684.669 \\
3768.243\end{array}$ & .217 \\
\hline $\begin{array}{l}\text { Superior Orientation } \\
\text { Between Groups } \\
\text { Within Groups } \\
\text { Total }\end{array}$ & $\begin{array}{r}3 \\
198 \\
201\end{array}$ & $\begin{array}{r}146.811 \\
7281.709 \\
7428.521\end{array}$ & .266 \\
\hline
\end{tabular}


APPENDIX $F(3)$

ANALYSIS OF VARIANCE OF TEACHERS' RESPONSES REGARDING

THEIR PRINCIPALS' LEADERSHIP BEHAVIOR ON TWELVE

DIMENSIONS : TEACHERS GROUPED ACCORDING

TO TEACHING EXPERIENCE

\begin{tabular}{|c|c|c|c|}
\hline Subscales & $D E$ & $\begin{array}{r}\text { Sum of } \\
\text { squares }\end{array}$ & $P$ \\
\hline $\begin{array}{l}\text { Representation } \\
\text { Between Groups } \\
\text { Within Groups } \\
\text { Total }\end{array}$ & $\begin{array}{r}2 \\
199 \\
201\end{array}$ & $\begin{array}{r}12.225 \\
1216.745 \\
1228.971\end{array}$ & .371 \\
\hline $\begin{array}{l}\text { Reconciliation } \\
\text { Between Groups } \\
\text { Within Groups } \\
\text { Total }\end{array}$ & $\begin{array}{r}2 \\
199 \\
201\end{array}$ & $\begin{array}{r}13.625 \\
2688.757 \\
2702.381\end{array}$ & .605 \\
\hline $\begin{array}{l}\text { Tolerance of Uncertainty } \\
\text { between Groups } \\
\text { Within Groups } \\
\text { Total }\end{array}$ & $\begin{array}{r}2 \\
199 \\
201\end{array}$ & $\begin{array}{r}36.248 \\
9226.905 \\
9263.154\end{array}$ & .677 \\
\hline $\begin{array}{l}\text { Persuasiveness } \\
\text { Between Groups } \\
\text { Within Groups } \\
\text { Total }\end{array}$ & $\begin{array}{r}2 \\
199 \\
201\end{array}$ & $\begin{array}{r}154.855 \\
8893.911 \\
9048.777\end{array}$ & .181 \\
\hline $\begin{array}{l}\text { Initiation of structure } \\
\text { Between Groups } \\
\text { Within Groups } \\
\text { Total }\end{array}$ & $\begin{array}{r}2 \\
199 \\
201\end{array}$ & $\begin{array}{r}60.999 \\
4837.378 \\
4898.376\end{array}$ & .287 \\
\hline $\begin{array}{l}\text { Tolerance of Freedom } \\
\text { Between Groups } \\
\text { Within Groups } \\
\text { Total }\end{array}$ & $\begin{array}{r}2 \\
199 \\
201\end{array}$ & $\begin{array}{r}171.661 \\
11422.022 \\
11593.683\end{array}$ & .227 \\
\hline
\end{tabular}

*Significant at the .05 level. 
ANALYSIS OF VARIANCE OF TEACHERS' RESPONSES REGARDING

THEIR PRINCIPALS' LEADEERSHIP BEHAVIOR ON TWELVE DIMENSIONS:TEACHERS GROUPED ACCORDING TO TEACHING EXPERIENCE

\begin{tabular}{|c|c|c|c|}
\hline Subscales & DF & $\begin{array}{r}\text { Sum of } \\
\text { Squares }\end{array}$ & $\underline{P}$ \\
\hline $\begin{array}{l}\text { Representation } \\
\text { Between Groups } \\
\text { Within Groups } \\
\text { Total }\end{array}$ & $\begin{array}{r}2 \\
199 \\
201\end{array}$ & $\begin{array}{r}12.225 \\
1216.745 \\
1228.971\end{array}$ & .371 \\
\hline $\begin{array}{l}\text { Reconciliation } \\
\text { Between Groups } \\
\text { Within Groups } \\
\text { Total }\end{array}$ & $\begin{array}{r}2 \\
199 \\
201\end{array}$ & $\begin{array}{r}13.625 \\
2688.757 \\
2702.381\end{array}$ & .605 \\
\hline $\begin{array}{l}\text { Tolerance of Uncertainty } \\
\text { Between Groups } \\
\text { Within Groups } \\
\text { Total }\end{array}$ & $\begin{array}{r}2 \\
199 \\
201\end{array}$ & $\begin{array}{r}36.248 \\
9226.905 \\
9263.154\end{array}$ & .677 \\
\hline $\begin{array}{l}\text { Persuasiveness } \\
\text { Between Groups } \\
\text { Within Groups } \\
\text { Total }\end{array}$ & $\begin{array}{r}2 \\
199 \\
201\end{array}$ & $\begin{array}{r}154.866 \\
8893.911 \\
9048.777\end{array}$ & .181 \\
\hline $\begin{array}{l}\text { Initiation of structure } \\
\text { Between Groups } \\
\text { Within Groups } \\
\text { Total }\end{array}$ & $\begin{array}{r}2 \\
199 \\
201\end{array}$ & $\begin{array}{r}60.999 \\
4837.378 \\
4898.376\end{array}$ & .287 \\
\hline $\begin{array}{l}\text { Tolerance of Ereedom } \\
\text { Between Groups } \\
\text { Within Groups } \\
\text { Total }\end{array}$ & $\begin{array}{r}2 \\
199 \\
201\end{array}$ & $\begin{array}{r}171.661 \\
11422.022 \\
11593.683\end{array}$ & .227 \\
\hline
\end{tabular}

×ignificant at the .05 level. 
APPENDIX F(3) CONTINUED

ANALYSIS OF VARIANCE OF TEACHERS' RESPONSES REGARDING
THEIR PRINCIPALS' LEADERSHIP BEHAVIOR ON TWELVE
DIMENSIONS: TEACHERS GROUPED ACCORDING
TO LEVELS OF TEACHING EXPERIENCE

\begin{tabular}{lrrr}
\hline Subscales & DF & Sum of & Squares \\
\hline Role Assumption & & & \\
Between Groups & 2 & 11.769 & .832 \\
Within Groups & 199 & 6366.974 & \\
Total & 201 & 6378.733 & \\
Consideration & & & \\
Between Groups & 2 & 118.344 & .314 \\
Within Groups & 199 & 10037.756 & \\
Total & 201 & 10216.099 & \\
Production Emphasis & & & \\
Between Groups & 2 & 10.161 & .886 \\
Within Groups & 199 & 8304.989 & \\
Total & 201 & 8315.149 & \\
& & & \\
Predictive Accuracy & & & \\
Between Groups & 2 & 963 \\
Within Groups & 199 & 1658.767 & \\
Total & 201 & 1668.376 & \\
Integration & & & \\
Between Groups & & & \\
Within Groups & 2 & 31.818 & .431 \\
Total & 199 & 3736.425 & \\
Superior Orientation & 201 & 3768.243 & \\
Between Groups & & & \\
Within Groups & 2 & 17.808 & \\
Total & 199 & 7410.712 & \\
& 201 & 7428.521 & \\
\hline
\end{tabular}

*Significant at the .05 level. 
APPENDIX $F(\Delta)$

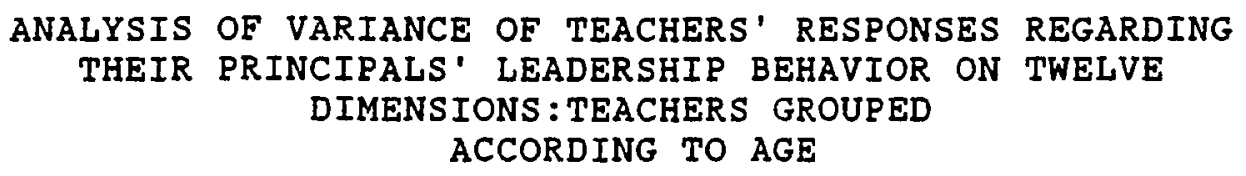

\begin{tabular}{|c|c|c|c|}
\hline \multirow[b]{2}{*}{ Subscales } & \multicolumn{3}{|c|}{ Sum of } \\
\hline & $D E$ & Squares & P \\
\hline $\begin{array}{l}\text { Representation } \\
\text { Between Groups } \\
\text { Within Groups } \\
\text { Total }\end{array}$ & $\begin{array}{r}2 \\
199 \\
201\end{array}$ & $\begin{array}{r}67.443 \\
1161.527 \\
1228.971\end{array}$ & $.004 *$ \\
\hline $\begin{array}{l}\text { Reconciliation } \\
\text { Between Groups } \\
\text { Within Groups } \\
\text { Total }\end{array}$ & $\begin{array}{r}2 \\
199 \\
201\end{array}$ & $\begin{array}{r}52.174 \\
2650.207 \\
2701.381\end{array}$ & .144 \\
\hline $\begin{array}{l}\text { Tolerance of Uncertainty } \\
\text { Between Groups } \\
\text { Within Groups } \\
\text { Total }\end{array}$ & $\begin{array}{r}2 \\
199 \\
201\end{array}$ & $\begin{array}{r}77.336 \\
9185.818 \\
9263.154\end{array}$ & .434 \\
\hline $\begin{array}{l}\text { Persuasiveness } \\
\text { Between Groups } \\
\text { Within Groups } \\
\text { Total }\end{array}$ & $\begin{array}{r}2 \\
199 \\
201\end{array}$ & $\begin{array}{c}274.887 \\
8773.89 \\
9048.777\end{array}$ & $.046 *$ \\
\hline $\begin{array}{l}\text { Initiation of structure } \\
\text { Between Groups } \\
\text { Within Groups } \\
\text { Total }\end{array}$ & $\begin{array}{r}2 \\
199 \\
201\end{array}$ & $\begin{array}{r}125.525 \\
4772.851 \\
4898.376\end{array}$ & .076 \\
\hline $\begin{array}{l}\text { Tolerance of Freedom } \\
\text { Between Groups } \\
\text { Within Groups } \\
\text { Total }\end{array}$ & $\begin{array}{r}2 \\
199 \\
201\end{array}$ & $\begin{array}{r}8.501 \\
11585.181 \\
11593.683\end{array}$ & .930 \\
\hline
\end{tabular}

Significant at the .05 level. 
APPENDIX (F4) CONTINUED

\begin{abstract}
ANALYSIS OF VARIANCE OF TEACHERS' RESPONSES REGARDING THEIR PRINCIPALS' LEADERSHIP BEHAVIOR ON TWELVE DIMENSIONS: TEACHERS GROUPED ACCORDING TO AGE
\end{abstract}

\begin{tabular}{|c|c|c|c|}
\hline \multirow[b]{2}{*}{ Subscales } & \multicolumn{3}{|c|}{ Sum of } \\
\hline & DF & ares & P \\
\hline $\begin{array}{l}\text { Role Assumption } \\
\text { Between Groups } \\
\text { Within Groups } \\
\text { Total }\end{array}$ & $\begin{array}{r}2 \\
199 \\
201\end{array}$ & $\begin{array}{r}259.887 \\
6118.845 \\
6378.733\end{array}$ & $.016 \star$ \\
\hline $\begin{array}{l}\text { Consideration } \\
\text { Between Groups } \\
\text { Within Groups } \\
\text { Total }\end{array}$ & $\begin{array}{r}2 \\
199 \\
201\end{array}$ & $\begin{array}{r}58.181 \\
10157.918 \\
10216.099\end{array}$ & .5678 \\
\hline $\begin{array}{l}\text { Production Emphasis } \\
\text { Between Groups } \\
\text { Within Groups } \\
\text { Total }\end{array}$ & $\begin{array}{r}2 \\
199 \\
201\end{array}$ & $\begin{array}{r}163.042 \\
8152.107 \\
8315.149\end{array}$ & .139 \\
\hline $\begin{array}{l}\text { Predictive Accuracy } \\
\text { Between Groups } \\
\text { Within Groups } \\
\text { Total }\end{array}$ & $\begin{array}{r}2 \\
199 \\
201\end{array}$ & $\begin{array}{r}49.706 \\
1618.671 \\
1668.376\end{array}$ & $.049 *$ \\
\hline $\begin{array}{l}\text { Integration } \\
\text { Between Groups } \\
\text { Within Groups } \\
\text { Total }\end{array}$ & $\begin{array}{r}2 \\
199 \\
201\end{array}$ & $\begin{array}{l}44.153 \\
3724.09 \\
3768.243\end{array}$ & .310 \\
\hline $\begin{array}{l}\text { Superior Orientation } \\
\text { Between Groups } \\
\text { Within Groups } \\
\text { Total }\end{array}$ & $\begin{array}{r}2 \\
199 \\
201\end{array}$ & $\begin{array}{r}105.678 \\
7322.842 \\
7428.521\end{array}$ & .240 \\
\hline
\end{tabular}


APPENDIX $E(5)$

ANALYSIS OF VARIANCE OF TEACHERS' RESPONSES REGARDING

THEIR PRINCIPALS' LEADERSHIP BEHAVIOR ON TWELVE

DIMENSIONS: TEACHERS GROUPEE ACCORDING

TO LEVELS OF TEACHING ASSIGNMENT

\begin{tabular}{|c|c|c|c|}
\hline Subscales & DF & $\begin{array}{r}\text { Sum of } \\
\text { Squares }\end{array}$ & $\underline{P}$ \\
\hline $\begin{array}{l}\text { Representation } \\
\text { Between Groups } \\
\text { Within Groups } \\
\text { Total }\end{array}$ & $\begin{array}{r}2 \\
199 \\
201\end{array}$ & $\begin{array}{r}.281 \\
1228.691 \\
1228.971\end{array}$ & .976 \\
\hline $\begin{array}{l}\text { Reconciliation } \\
\text { Between Groups } \\
\text { Within Groups } \\
\text { Total }\end{array}$ & $\begin{array}{r}2 \\
199 \\
201\end{array}$ & $\begin{array}{r}5.917 \\
2696.464 \\
2702.381\end{array}$ & .804 \\
\hline $\begin{array}{l}\text { Tolerance of Uncortainty } \\
\text { Between Groups } \\
\text { Within Groups } \\
\text { Total }\end{array}$ & $\begin{array}{r}2 \\
199 \\
201\end{array}$ & $\begin{array}{r}14.563 \\
9248.591 \\
9263.154\end{array}$ & .855 \\
\hline $\begin{array}{l}\text { Persuasiveness } \\
\text { Between Groups } \\
\text { Within Groups } \\
\text { Total }\end{array}$ & $\begin{array}{r}2 \\
199 \\
201\end{array}$ & $\begin{array}{r}84.716 \\
8964.062 \\
9048.777\end{array}$ & .392 \\
\hline $\begin{array}{l}\text { Initiation of structure } \\
\text { Between Groups } \\
\text { Within Groups } \\
\text { Total }\end{array}$ & $\begin{array}{r}2 \\
199 \\
201\end{array}$ & $\begin{array}{r}60.182 \\
4838.194 \\
4898.376\end{array}$ & .292 \\
\hline $\begin{array}{l}\text { Tolerance of Freedom } \\
\text { Between Groups } \\
\text { Within Groups } \\
\text { Total }\end{array}$ & $\begin{array}{r}2 \\
199 \\
201\end{array}$ & $\begin{array}{l}.1973 \\
115593.511 \\
11593.683\end{array}$ & .995 \\
\hline
\end{tabular}

* Significant at the .05 level. 
APPENDIX F(5) CONTINUED

ANALYSIS OF VARIANCE OF TEACHERS' RESPONSES REGARDING

THEIR PRINCIPALS' LEADERSHIP BEHAVIOR ON TWELVE

DIMENSIONS: TEACHERS GROUPED ACCORDING

TO TEACHING ASSIGNMENT

\begin{tabular}{|c|c|c|c|}
\hline Subscales & $\mathrm{DE}$ & $\begin{array}{r}\text { Sum of } \\
\text { squares }\end{array}$ & $\underline{P}$ \\
\hline $\begin{array}{l}\text { Role Assumption } \\
\text { Between Groups } \\
\text { Within Groups } \\
\text { Total }\end{array}$ & $\begin{array}{r}2 \\
199 \\
201\end{array}$ & $\begin{array}{r}17.811 \\
6360.921 \\
6378.733\end{array}$ & .757 \\
\hline $\begin{array}{l}\text { Consideration } \\
\text { Between Groups } \\
\text { Within Groups } \\
\text { Total }\end{array}$ & $\begin{array}{r}2 \\
199 \\
201\end{array}$ & $\begin{array}{r}8.813 \\
10207.286 \\
10216.099\end{array}$ & .918 \\
\hline $\begin{array}{l}\text { Production Emphasis } \\
\text { Between Groups } \\
\text { Within Groups } \\
\text { Total }\end{array}$ & $\begin{array}{r}2 \\
199 \\
201\end{array}$ & $\begin{array}{r}146.632 \\
8168.517 \\
8315.149\end{array}$ & .171 \\
\hline $\begin{array}{l}\text { Predictive Accuracy } \\
\text { Between Groups } \\
\text { Within Groups } \\
\text { Total }\end{array}$ & $\begin{array}{r}2 \\
199 \\
201\end{array}$ & $\begin{array}{r}13.756 \\
1654.621 \\
1668.376\end{array}$ & .439 \\
\hline $\begin{array}{l}\text { Integration } \\
\text { Between Groups } \\
\text { Within Groups } \\
\text { Total }\end{array}$ & $\begin{array}{r}2 \\
199 \\
201\end{array}$ & $\begin{array}{r}30.224 \\
3738.019 \\
3768.243\end{array}$ & .449 \\
\hline $\begin{array}{l}\text { Superior Orientation } \\
\text { Between Groups } \\
\text { Within Groups } \\
\text { Total }\end{array}$ & $\begin{array}{r}2 \\
199 \\
201\end{array}$ & $\begin{array}{r}86.676 \\
7341.844 \\
7428.521\end{array}$ & .311 \\
\hline
\end{tabular}

*Significant at the .05 level. 